\title{
LA JUSTICIA CONSTITUCIONAL DEL GENERAL GUSTAVO ROJAS PINILLA: ENTRE EL TRIBUNAL DE GARANTÍAS CONSTITUCIONALES Y LA SALA DE NEGOCIOS CONSTITUCIONALES. COLOMBIA, 1953-1957 ${ }^{1}$
}

\author{
THE CONSTITUTIONAL JUSTICE OF GENERAL \\ GUSTAVO ROJAS PINILLA: BETWEEN THE \\ CONSTITUTIONAL TRIBUNAL AND THE CONSTITUTIONAL \\ AFFAIRS CHAMBER. COLOMBIA, 1953-1957
}

\author{
Mario Alberto Cajas Sarria \\ Universidad Icesi, Colombia
}

SUMARIO: I. INTRODUCCIÓN.- II. DEL GOLPE MILITAR A LA REFORMA JUDICIAL: EL TRIBUNAL DE GARANTÍAS CONSTITUCIONALES DE 1953. 2.1. La caída del gobierno de Laureano Gómez y el golpe militar del 13 de junio de 1953. 2.2. De las buenas relaciones a la ruptura: reforma judicial y "crisis" de la justicia. 2.3. El general Rojas Pinilla propone un Tribunal de Garantias Constitucionales. 2.4 ¿E1 Tribunal de Garantias Constitucionales de España viaja a Colombia? 2.5. Las voces sobre la reforma: crisis judicial.- III. LA SALA DE NEGOCIOS CONSTITUCIONALES DE 1956: EL LÍMITE AL CONTROL CONSTITUCIONAL DE LA CORTE SUPREMA SE CONCRETA. 3.1. La nueva Corte Suprema y el clima de entendimiento con el régimen militar, 1954. 3.2. Rojas quiere gobernar con menos limites: la Sala de Negocios Constitucionales de 1956.- IV. REFLEXIONES FINALES.

Resumen: Este artículo examina las reformas y los intentos de reforma a la justicia constitucional del gobierno del general Gustavo Rojas Pinilla, quien ejerció el poder en Colombia entre 1953 y 1957. En particular, analiza las propuestas del régimen militar que buscaban modificar el control constitucional de las leyes que estaba a cargo de la Corte Suprema de Justicia desde 1910. Primero aborda el proyecto de creación de un Tribunal de Garantías Constitucionales (TGC), en medio de la confrontación entre el Ejecutivo y la Corte en noviembre de 1953, institución que en parte se habría inspirado en el TGC de la constitución española de 1931. Luego se ocupa de la creación de la Sala de Negocios Constitucionales dentro de la Corte Suprema de Justicia en 1956. Si bien el general Rojas justificó los cambios con el argumento de "tecnificar" la defensa judicial de la Constitución en Colombia, este trabajo revela que ambas iniciativas reformistas se producen en medio de las

1 Este artículo hace parte del proyecto de investigación: "El control judicial a las reformas constitucionales en Colombia, que desarrolla el autor en el Grupo de investigación Precedente de la Facultad de Derecho y Ciencias Sociales de la Universidad Icesi Proyecto 655-2016). 
tensiones politicas entre la Corte Suprema y un gobierno militar cuyo verdadero propósito era controlar la justicia y limitar a su juez constitucional.

Abstract: This paper deals with the reforms and attempts to reform the constitutional justice by General Gustavo Rojas Pinilla, who ruled Colombia between 1953 and 1957. In particular, it discusses the proposals of the military rule that sought to change the judicial review of legislation exercised by the Supreme Court since 1910. First, it discusses the project of creating a Tribunal de Garantias Constitucionales (Constitutional Tribunal) amid of the confrontation between the Executive branch and the Supreme Court in November, 1953, a Tribunal partly inspired by the Tribunal de Garantias Constitucionales of the Constitution of Spain of 1931. Then, it tells the story of the creation of the Constitutional Chamber in the Supreme Court in 1956. While Rojas justified the overall changes on the grounds of "technify" the judicial review in Colombia, this article reveals that both reform initiatives come amid political tensions between the Court and a military rule whose real purpose was to take control of the Judiciary and to limit his constitutional judge.

Palabras clave: historia constitucional, justicia constitucional y dictadura, historia judicial colombiana, justicia constitucional colombiana.

Keywords: Constitutional History, Judicial Review and Dictatorship, Colombian Judicial History and Colombian Constitutional Justice.

\section{INTRODUCCIÓN}

En la literatura académica hay muy pocos estudios sobre las reformas a la justicia en Colombia ${ }^{2}$; son aun menos los que rastrean la trayectoria de la justicia constitucional en una perspectiva histórica y política ${ }^{3}$ y no existen trabajos que

2 Una reconstrucción de las reformas a la justicia en el siglo veinte colombiano aparece en la segunda parte del tomo I de Boaventura Souza Santos y Mauricio Garcia Villegas. El Caleidoscopio de las Justicias en Colombia. Bogotá, Colciencias, ICANH, Uniandes, Universidad Nacional de Colombia, Siglo del Hombre Editores. Bogotá, 2001. Para el caso de la justicia administrativa véase: Juan Pablo Sarmiento: Surgimiento de la dualidad de jurisdicciones en Colombia: entre la Regeneración, la dictadura y la Unión Republicana, Universidad del Norte- Grupo Editorial Ibáñez, Barranquilla, 2012.

3 Dentro de la literatura que en la región aborda la historia de las Cortes con perspectiva politica y bajo diferentes enfoques, véanse: Timothy M. James: Mexico's Supreme Court: Between Liberal, Individual and Revolutionary Social Rights, 1867-1914, University of New Mexico Press, 2013, también Héctor José Tanzi: "Historia ideológica de la Corte Suprema de Justicia de la Nación" (1903-1930), Revista Iushistoria No. 1, Buenos Aires, 2008; Eduardo Oteiza, La Corte Suprema: entre la justicia sin politica y la política sin justicia, Librería Editora Platense, La Plata, 1994, y José Reinaldo De Lima Lopes: El oráculo de Delfos: Consejo de Estado y derecho en Brasil Imperial, Fontamara, México, D.F., 2012. Para el caso de la Corte Suprema de Justicia colombiana véanse: Jorge González Jácome: Entre la ley y la Constitución: una introducción histórica de la función institucional de la Corte Suprema de Justicia, 1886- 1915. Pontificia Universidad Javeriana, Facultad de Ciencias Jurídicas, Bogotá. 2007, y Mario A. Cajas Sarria: El control judicial a la reforma constitucional, 1910-2007, Universidad Icesi, Cali, 2008. Un interesante estudio histórico y político sobre el proceso de la construcción institucional del poder judicial federal y de la Corte Suprema para el caso de los Estados Unidos es el de Justin 
analicen cómo los regímenes políticos autoritarios también contribuyeron a moldear esa institución.

Este artículo continúa una agenda de investigación que busca reconstruir la trayectoria de la justicia constitucional colombiana en una perspectiva histórica y política4. En particular, examina las reformas y los intentos de reforma a la justicia constitucional del general Gustavo Rojas Pinilla, quien siendo comandante general de las Fuerzas Militares dio un golpe de Estado al presidente Laureano Gómez el 13 de junio de 1953 y gobernó el país hasta entregar el poder a la Junta Militar de Gobierno el 10 de mayo de $1957^{5}$. Las dos iniciativas reformistas del general Rojas que se evalúan en este trabajo buscaban modificar el control constitucional de las leyes atribuido a la Corte Suprema de Justicia ${ }^{6}$ por la reforma constitucional del Acto Legislativo No. 03 de $1910^{7 .}$

El primer proyecto de reforma judicial del general Gustavo Rojas Pinilla fue anunciado públicamente en noviembre de 1953, muy poco tiempo después de que pareciera reinar un clima de armonía entre la Corte Suprema de Justicia y el régimen militar. El Ejecutivo, en medio de agudas críticas a la rama judicial, buscó modificar el diseño institucional de la Corte y propuso la creación de un Tribunal de Garantias Constitucionales (en adelante TGC), que sería juez constitucional en lugar de la Corte Suprema. Si bien la iniciativa no se concretó, las tensiones politicas entre el Ejecutivo y la rama judicial desencadenaron la renuncia del pleno de la Corte. Con la dimisión de los magistrados, Rojas pudo conformar una nueva Corte Suprema de Justicia que entró en funciones en enero de 1954.

Crowe: Building the Judiciary: Law, Courts and the Politics of Institutional Development. Princeton University Press, 2012.

${ }^{4}$ La reconstrucción historiográfica y política del control judicial de la Constitución aparece en: Mario Alberto Cajas Sarria, La Historia de la Corte Suprema de Justicia de Colombia, 1886-1991, Tomo I: de la Regeneración al régimen militar, 1886-1958 y Tomo II: Del Frente Nacional a la Asamblea constituyente, 1958-1991, Universidad de los Andes y Universidad Icesi, Bogotá, 2015.

${ }^{5} \mathrm{El}$ análisis de las relaciones entre la Corte y el gobierno del general Rojas, así como del control constitucional en ese período en: Mario Alberto Cajas Sarria, "La Corte Suprema de Justicia bajo el gobierno del general Gustavo Rojas Pinilla" Revista de Estudios Sociales 50, Universidad de los Andes, Bogotá, 2014.

6 Sobre los orígenes de la acción pública de inconstitucionalidad y la defensa judicial de la constitución por la Corte véase: Mario Alberto Cajas Sarria, "La Corte Suprema de Justicia de Colombia, 1886-1910: de juez de la Regeneración a juez constitucional", Historia Constitucional No. 14, 2013. Pp. 425-465. Andrés Botero Bernal analiza desde la historia y el derecho constitucional la singularidad del caso colombiano en: "Haciendo memoria de la defensa judicial de la Constitucional, Pensamiento Jurídico, No. 20, Bogotá, 2007.

7 Este era el texto de la reforma: "Artículo 41. A la Corte Suprema se le confia la guarda de la integridad de la Constitución. En consecuencia, además de las facultades que le confieren ésta y las leyes, tendrá la siguiente: Decidir definitivamente sobre la exequibilidad de los Actos Legislativos que hayan sido objetados como inconstitucionales por el Gobierno, o sobre todas las leyes o decretos acusados ante ella por cualquier ciudadano como inconstitucionales, previa audiencia del Procurador General de la Nación”. Acto Legislativo 03 del 31 de octubre de 1910. En: Carlos Restrepo Piedrahita (Comp.), Constituciones Nacionales de Colombia, Universidad Externado de Colombia, $3^{a}$ edición, Bogotá, 2003. P. 464. 
La segunda iniciativa de reforma a la justicia constitucional del general Rojas fue en 1956 y sí se llevó a cabo. Mediante un decreto de estado de sitio el Ejecutivo creó una Sala de Negocios Constitucionales dentro de la Corte Suprema de Justicia y le asignó el control constitucional de las leyes, que estaba a cargo de la Sala Plena desde la mencionada reforma de 1910. Varios magistrados reaccionaron a esa modificación en el diseño institucional con la renuncia a sus cargos pero Rojas proveyó rápidamente las vacantes y logró que la nueva Sala funcionara como un "pequeño tribunal constitucional" dentro de la propia Corte Suprema. La Sala de Negocios Constitucionales ejerció como juez constitucional incluso hasta un poco después de que Rojas dejó el poder pues la Junta Militar de Gobierno que lo sucedió la disolvió el 19 de julio de 1957.

Este trabajo sostiene que las dos iniciativas reformistas del general Rojas a la justicia constitucional se inscriben en un ambiente de tensiones politicas entre el régimen militar y la rama judicial originadas por los intentos del Ejecutivo de tener una mayor influencia en la Corte Suprema de Justicia, que para la época era tribunal de casación, la cabeza de la justicia ordinaria y juez constitucional. Así, no obstante que el gobierno formuló argumentos de tipo "técnico" para justificar los cambios a la justicia constitucional en tiempos en que la opinión pública percibía a la rama judicial como poco eficaz, este artículo revela el trasfondo de esas propuestas: la intención del Ejecutivo de tomar el control de la Corte Suprema y a través de ella del no siempre dócil poder judicial.

De este modo, las dos iniciativas del gobierno del general Gustavo Rojas Pinilla, que poco se analizan o no se tienen en cuenta cuando se aborda la construcción institucional de la justicia constitucional en Colombia, comportan una paradoja. El gobierno militar, que suele caracterizarse como la dictadura que irrumpe en 1953, aparece como el gran interesado en "fortalecer" la guarda de la integridad y supremacía de la Constitución. Es decir, que desde una perspectiva puramente técnica, el régimen militar proponía la modificación del control constitucional de la Corte Suprema de Justicia para asignarlo a "especialistas" en derecho público, primero con el TGC que sería un tribunal constitucional especializado de tipo concentrado y luego con la Sala de Negocios Constitucionales, pero con ambas iniciativas buscaba una institucionalidad que daba clara preeminencia al Ejecutivo sobre la justicia constitucional ${ }^{8}$.

Esta historia de la agenda reformista del general Rojas a la justicia constitucional también propone volver la mirada a los "antecedentes" de la Corte Constitucional Colombiana. La narrativa canónica de los orígenes de ese órgano suele centrarse en los intentos fallidos de crear un tribunal constitucional especializado y concentrado, del tipo europeo inspirado en Kelsen, en la reforma

8 Para un estudio comparado global sobre la justicia en dictaduras, incluyendo a Chile, Argentina y Colombia véase: Ginsburg, Tom y Moustafa, Tamir (Eds.) Rule by Law: The Politics of Courts in Authoritarian Regimes, Cambridge University Press, 2008. Sobre el poder judicial bajo dictaduras en el caso de Argentina: Helmke, Gretchen. Courts under constraints: Judges, Generals and Presidents in Argentina, Cambridge University Press, 2012. En el contexto chileno: Hilbink, Lisa. Judges beyond Politics in Democracy and Dictatorship: Lessons from Chile, Cambridge University Press, 2007. 
constitucional de 1968.9 En este sentido, el artículo hace visible un "eslabón perdido" de esos antecedentes: el Tribunal de Garantías Constitucionales que rondó la mente de juristas y del Ejecutivo en la década de los cincuenta del siglo veinte colombiano.

Por último, el artículo se organiza del siguiente modo. Inicia con un breve contexto de la coyuntura de la llegada del general Gustavo Rojas Pinilla a la presidencia de la República en 1953. Luego narra las tensiones del gobierno militar con la Corte Suprema de Justicia que enmarcan la reforma judicial propuesta a finales de ese mismo año, y se ocupa en detalle de la iniciativa de crear un Tribunal de Garantias Constitucionales, que en parte parecía inspirarse en su homólogo de la Constitución de la II República Española de 1931. Después aborda la creación de la Sala de Negocios Constitucionales dentro de la Corte Suprema de Justicia en 1956. Al cierre se ofrecen unas reflexiones.

\section{DEL GOLPE MILITAR A LA REFORMA JUDICIAL: EL TRIBUNAL DE GARANTÍAS CONSTITUCIONALES DE 1953.}

\subsection{La caída del gobierno de Laureano Gómez y el golpe militar del 13 de junio de 1953.}

El dirigente conservador Laureano Gómez ganó la Presidencia de la República para el período constitucional 1950- 1954, luego de una campaña electoral marcada por la violencia bipartidista en la que el Partido Liberal retiró su candidato denunciando la falta de garantías electorales y la represión sectaria del gobierno conservador de Mariano Ospina Pérez (1946-195010.

Gómez, el más férreo opositor de llamada Segunda República Liberal que gobernó a Colombia entre 1930 y 194511, desde su campaña presidencial anunció sus intenciones de llevar a cabo una profunda reforma constitucional,

\footnotetext{
${ }^{9}$ Sin duda la narrativa canónica nos la ofrece el profesor Carlos Restrepo Piedrahita, quien no solo hizo parte de la intelligentsia que abogó por el tribunal constitucional concentrado y especializado de tipo europeo, como artífice de la reforma de 1968, sino durante toda la segunda mitad del siglo veinte. Carlos Restrepo Piedrahita. Tres ideas constitucionales: Supremacía de la Constitución, Corte Constitucional, El Ombudsman. Universidad Externado de Colombia, Bogotá, 1978.

10 Gómez se posesionó ante la Corte Suprema de Justicia pues el Congreso de la República se encontraba cerrado desde que el presidente Ospina Pérez lo cerró por decreto de estado de sitio No. 3518 del 9 de noviembre de 1949. En la posesión de Gómez fue memorable el discurso laudatorio de su llegada al poder y de los gobiernos conservadores que pronunció el presidente de la Corte Suprema, Domingo Sarasty. Mario Alberto Cajas Sarria, La historia de la Corte Suprema de Justicia de Colombia, 1886-1991. Tomo I, op cit. Pp. 327-330.

11 Sobre la enconada oposición de Gómez a los gobiernos liberales y en especial a la reforma constitucional de 1936 hay bibliografia extensa. Por ejemplo: James D. Henderson, Las ideas de Laureano Gómez. Tercer Mundo Editores, Bogotá, 1985, y James D. Henderson, Modernization in Colombia: the Laureano Gómez years, 1889-1965, University Press of Florida, 2001. La version en español: La modernización en Colombia: los años de Laureano Gómez, 1889-1965. Traducción de Magdalena Holguín. Universidad de Antioquia, Medellin 2006.
} 
que en parte debía restablecer la Constitución de $1886,{ }^{12}$ y que pretendía borrar de un tajo el constitucionalismo social y laico de la reforma constitucional liberal de $1936^{13}$.

A medida que el gobierno de Gómez avanzaba, la violencia en el país se incrementaba, la oposición al Ejecutivo desde varios sectores era cada vez mayor y algunos de ellos empezaban a mostrar su interés en la intervención del Ejército. El Partido Liberal sufría agresiones en contra de sus militantes y su dirigencia, en 1952 el expresidente Alfonso López Pumarejo y el ex ministro Carlos Lleras Restrepo optaron por el exilio luego de que sus residencias fueran incendiadas en Bogotá ante la mirada obsecuente de las autoridades. Los empresarios tampoco estaban de acuerdo con el manejo macroeconómico del gobierno. Por último, el Partido Conservador estaba fuertemente dividido entre los partidarios del expresidente Mariano Ospina Pérez, en abierta oposición contra el gobierno y quien ya había anunciado su candidatura a la presidencia para el periodo 1954-1958, y por supuesto entre quienes respaldaban a Gómez ${ }^{14}$. Debido a sus padecimientos de salud, el presidente Laureano Gómez tuvo que ceder temporalmente su cargo al Designado a la Presidencia, Roberto Urdaneta Arbeláez, el 5 de noviembre de $1951^{15}$.

Gómez, por intermedio de Roberto Urdaneta en la Presidencia de la República, logró que el Congreso de la República integrado exclusivamente por conservadores

12 Gómez, quien no ahorraba elogios para la Constitución 1886, una Carta de talante autoritario, conservador y centralista, y consideraba que las reformas liberales la habian desvirtuado. Esto afirmaba sobre la Carta Politica: "La Constitución de 1886 es una realización insigne de sabiduría social y politica que enorgullece con justicia a quienes han nacido y crecido bajo su amparo (...) Sus autores egregios y videntes, supieron colocarse entre los vértices helados de la doctrina alemana y el positivismo concreto de la doctrina anglo-americana, iluminando los descubrimientos de la ciencia filosófica y politica con luz eterna encendida en la colina de las bienaventuranzas. El noble espíritu de los constituyentes amaba la libertad, pero también el orden; establecía la democracia sin caer en la demagogia; fundaba la República excluyendo al tirano y al anarquista; sabía dónde estaba el origen del poder y cuáles eran las condiciones de su ejercicio porque había leído y obedecía el gran principio de San Pablo: "Omnis potestas a Deo per populum". "La Constitución de 1886", tomado de El Siglo, 6 de agosto de 1936, en: Ricardo Ruíz Santos: Laureano Gómez, Obra selecta, 1909-1956. Publicación del Senado de la República, Imprenta Nacional, Bogotá, 1982.

13 "Gómez representaba el renacer de la tradición antidemocrática y antiliberal...En su visión, las comunidades politicas debian concentrarse en el orden para evitar los problemas del liberalismo el cual, con su énfasis en derechos y libertades individuales habia puesto al país al borde de la revolución social y la desintegración en la década de 1860 y nuevamente en los años treinta". Jorge González Jácome. Estados de excepción y democracia liberal en América del Sur: Argentina, Chile y Colombia, 1920-1990, Editorial Pontificia Universidad Javeriana, Bogotá, 2015. P. 113.

14 Adolfo León Atehortúa, "El golpe de Rojas y el poder de los militares". Revista Folios Segunda época, 31: 33-48. Universidad Pedagógica Nacional, Tunja, Pp. 35-37.

15 Álvaro Tirado Mejía, "El gobierno de Laureano Gómez: de la dictadura civil a la dictadura militar". En Nueva Historia de Colombia: Historia Política, 1946-1986, Dir. Álvaro Tirado Mejía. Bogotá: Planeta. P. 95. 
aprobara el acto legislativo 01 del 9 de diciembre de $1952^{16}$, que convocó a una Asamblea Nacional Constituyente (ANAC) ${ }^{17}$ cuyo propósito era cumplir la anhelada contrarreforma antiliberal ${ }^{18}$. El proyecto de reforma constitucional que discutiría la ANAC fue preparado por una Comisión de Estudios Constitucionales (CEC) nombrada por el gobierno, que presentó su propuesta el 11 de febrero de $1953^{19}$. Estas eran algunas de las modificaciones que planteaba el proyecto de corte corporativista y autoritario de la CEC: Aparte de los Senadores elegidos en representación de cada Departamento ${ }^{20}$ habría quince más que serían "voceros de los intereses corporativos" de profesiones, oficios e instituciones tales como los industriales, ganaderos, comerciantes, trabajadores del Estado, de la Industria y del Comercio, trabajadores agrícolas, universidades, clero, profesiones liberales, institutos académicos y científicos; de igual modo reducía la duración de las sesiones del Congreso y lo despojaba de su facultad de investigar y juzgar al Presidente de la República. Asimismo, creaba un sistema autoritario que

$16 \mathrm{E}$ acto legislativo establecía limites al poder de reforma de la ANAC y prohibía que sustituyera al Congreso de la República en su función legislativa: "ARTÍCULO 7o. La Asamblea Nacional, por el hecho de ser exclusivamente constituyente, no tendrá las funciones legislativas adscritas al Congreso, y éste continuará cumpliéndolas en la forma que ordena la Constitución. Dicha Constituyente no podrá modificar el periodo constitucional en curso, del Presidente de la República, del Designado y del Congreso Nacional, salvo en lo referente a la Cámara de Representantes, cuyo periodo puede ampliar, haciéndolo igual al del Senado de la República". Acto legislativo 03 del 10 de diciembre de 1952, Diario Oficial No. 28075 del 12 de diciembre de 1952.

17 Los diputados de la ANAC no serían elegidos por voto popular. Esta sería la conformación: Un diputado por cada Departamento, elegidos por el Senado de la República; uno por cada Departamento, elegidos por la Cámara de Representantes; los ciudadanos que hayan ejercido el Poder Ejecutivo como titulares, designados o encargados; seis miembros designados por el Presidente de la República representando paritariamente a los partidos Liberal y Conservador; cuatro miembros elegidos por la Corte Electoral; dos ex-Magistrados de la Corte Suprema de Justicia, elegidos por ésta y pertenecientes a los dos partidos mencionados ; dos ex-Consejeros de Estado, elegidos por el mismo órgano, diez representantes de estas entidades, elegidos por ellas: Sociedad de Agricultores de Colombia, Asociación Colombiana de Ganaderos, Asociación Bancaria, Asociación Nacional de Industriales, Federación Nacional de Cafeteros, Federación Nacional de Comerciantes, Federación Nacional de Cooperativas, Organismos Nacionales de Sindicatos, "La prensa hablada y escrita del país", y "Las Universidades o Institutos docentes de enseñanza profesional, autorizados por la ley para expedir títulos académicos, representados, conjuntamente por sus Rectores o Directores, para elegir el delegatario que les corresponda". Artículo $1^{\circ}$, Acto legislativo 03 del 10 de diciembre de 1952, op. Cit.

18 En buena parte el ideario de Gómez se inspiraba en el corporativismo de la España de Franco y del Portugal de Oliveira Salazar. Miguel Malagón Pinzón y Diego Nicolás Pardo Motta. "Laureano Gómez, la Misión Currie y el proyecto de reforma constitucional de 1952”, Criterio Jurídico, V. 9. No. 2, Cali, 2009. P.10.

19 Entre los miembros de la CEC estaban prestigiosos constitucionalistas de origen conservador como Francisco de Paula Pérez y Alfredo Araujo Grau.

20 Para ser elegido senador se requería haber desempeñado altos cargos en el Estado, como vicepresidente de la República, Congresista, Procurador General, Gobernador de Departamento, Ministro del Despacho, Embajador o Magistrado de la Corte Suprema o del Consejo de Estado. "Proyecto de Reformas presentado al Ministerio de Gobierno por la Comisión de Estudios Constitucionales”, Bogotá, febrero 11 de 1953. Universidad Pontificia Bolivariana, Revista de Derecho, Vol. 3, 9-12, Medellin, 1953. Pp. 85-123. P. 98 
incrementaba el poder del Presidente de la República, por ejemplo aumentaba su período a seis años. El proyecto también era confesional: le confiaba la educación a la Iglesia Católica y tampoco se permitiría la profesión de un culto que fuera contrario a la moral de dicha iglesia. De igual modo, se establecía un régimen de censura previa para la "prensa hablada" y hasta se declaraba que: "El Estado Colombiano condena la lucha de clases y promueve la armonía social al amparo de la justicia"21. En cuanto a la Corte Suprema de Justicia, la elección de los magistrados no la haría el Congreso sino los Tribunales Superiores de los Distritos Judiciales del país y el período de las magistraturas se ampliaba a ocho años con posibilidad de reelección indefinida ${ }^{22}$.

El 15 de junio de 1953 la ANAC debía empezar a discutir la reforma constitucional propuesta por la CEC pero no pudo hacerlo pues el 13 de junio el general Gustavo Rojas Pinilla ${ }^{23}$, comandante general de las Fuerzas Armadas, asumió el poder ejecutivo tras dar un golpe de estado al presidente Gómez.

Con el clima político del momento no era una sorpresa que el general Rojas fuera protagonista del golpe. Este exitoso militar, que había sido Ministro de Correos y Telégrafos y comandante del Ejército bajo el gobierno de Ospina Pérez, siempre había generado la desconfianza del presidente. Por ejemplo, en 1951 Gómez ordenó su asignación en un cargo en el exterior y lo reemplazó en el ejército por el general Régulo Gaitán, amigo muy cercano al presidente. Luego, una vez Urdaneta asumió la presidencia nombró a Rojas como comandante de las Fuerzas Militares a finales de 1952, lo cual por supuesto molestó profundamente a Gómez. Desde ese cargo el general Rojas seguía confirmando las sospechas del presidente: en abril de 1953 Gómez lo hizo designar jefe de la misión que representaría al gobierno en la recién inaugurada ruta Bogotá- Frankfurt de la aerolínea Avianca pero a última hora la oficialidad militar lo logró convencer de la inconveniencia de su viaje a Europa,

21 "Proyecto de Reformas presentado al Ministerio de Gobierno por la Comisión de Estudios Constitucionales", Bogotá, febrero 11 de 1953. Ibíd. P. 92.

22 Sin embargo el proyecto aseguraba que el gobierno de Laureano Gómez tendría injerencia directa en la conformación de la primera Corte Suprema de Justicia que ejercería funciones a la entrada en vigencia de la reforma constitucional. En efecto, el Presidente de la República designaría a la mitad de los magistrados con aprobación del Senado y la otra mitad sería elegida de este modo: una cuarta parte por el Presidente de la República, de ternas propuestas por los decanos de las Facultades de Derecho y una cuarta parte por el Senado, de ternas presentadas por los Tribunales Superiores de Distrito. Proyecto de Reformas presentado al Ministerio de Gobierno por la Comisión de Estudios Constitucionales”. Ibíd. P.111.

23 Sobre el gobierno de Rojas, véanse: Vernon Lee Fluharty, La danza de los millones. Régimen militar y revolución social en Colombia (1930-1956), El Áncora Editores,Bogotá, 1981; Carlos Horacio Urán,Rojas y la manipulación del poder: Rojas Pinilla en la violencia y el poder, Carlos Valencia Editores, Bogotá, 1983; Alberto Donadio y Silvia Gálvis, El jefe supremo. Rojas Pinilla en la violencia y en el poder, Bogotá, Planeta,1988; Álvaro Tirado Mejía, "Rojas Pinilla: del golpe de opinión al exilio", Nueva Historia de Colombia, Historia Politica, 1946-1986, Dir. Álvaro Tirado Mejía, Bogotá, Planeta, 1989; César Augusto Ayala: "El discurso de la reconciliación. Análisis cuantitativo de las intervenciones de Gustavo Rojas Pinilla entre 1952 y 1959", Anuario Colombiano de Historia Social y de la Cultura 18/19, 1991, y Adolfo León Atehortúa, "El golpe de Rojas y el poder de los militares", Revista Folios Segunda época, 31: 33-48: Universidad Pedagógica Nacional, Tunja, 2010. 
pues sospechaban que sería llamado a calificar servicios estando fuera del país; la decisión de Rojas de permanecer en Colombia fue recibida con júbilo por las tropas $^{24}$.

Pero la ruptura definitiva entre el general Rojas y Gómez vino tras la detención y tortura del empresario antioqueño Felipe Echavarría Olózaga, a quien el Ejército acusó de terrorismo y de pretender conspirar contra Rojas. En cuanto Gómez se enteró de los hechos le pidió al Urdaneta la libertad inmediata de Echavarría y la remoción de Rojas de su cargo. Como Urdaneta se negó a cumplir la orden, Gómez reasumió la Presidencia de la República, citó de inmediato al Consejo de Ministros y le pidió al ministro de Guerra, Lucio Pabón Núñez, que removiera al general Rojas. Pabón prefirió renunciar antes que acatar la orden presidencial por lo que Gómez nombró a Jorge Leyva como Ministro de Defensa y le dio la orden de nombrar al general Régulo Gaitán en reemplazo de Rojas. Sin embargo, la medida en contra del general Gustavo Rojas Pinilla no se pudo hacer efectiva pues este se tomó el poder.

El golpe de estado del general Gustavo Rojas Pinilla no fue un acto solitario ni una acción aislada de las Fuerzas Armadas pues tanto sectores conservadores opuestos a Laureano Gómez como el liberalismo apoyaron el golpe. Rojas era visto como el mesías que llegaba a salvar la nación de la aguda violencia bipartidista que venía enfrentando a liberales y conservadores durante casi una década, y que se había recrudecido bajo el gobierno de Gómez. Esto explica en buena medida por qué tan pronto como el general asumió el poder de facto, la Asamblea Nacional Constituyente (ANAC), presidida por Mariano Ospina Pérez, aprobó el acto legislativo 01 del 18 de junio de 1953 y declaró que el 13 de junio "habia quedado vacante la Presidencia de la República" de modo que era "legítimo el título del actual Presidente de la República, Teniente General Gustavo Rojas Pinilla", quien ejercería ese cargo por el resto del período presidencial, es decir hasta $1954^{25}$.

\subsection{De las buenas relaciones a la ruptura: reforma judicial y "crisis" de la justicia.}

La rama judicial no fue la excepción a ese "clamor nacional" por la salida de Laureano Gómez del poder. Por ejemplo, la Corte Suprema de Justicia en una memorable manifestación del 15 de junio de 1953 expresó su respaldo al general Rojas pues en criterio de la corporación este había prometido que el gobierno militar era transitorio y buscaba restablecer plenamente la democracia. Esto manifestó la Corte: "al conocer que "se ha encargado de la presidencia de la república el Excelentísimo Teniente General Gustavo Rojas Pinilla, le presenta su atento saludo, le

24 "Itinerario de un golpe de estado", Revista Semana, 7 de mayo de 1993, recuperado el 4 de diciembre de 2015 en: http://www.semana.com/nacion/articulo/itinerario-golpe-estado/20128-3.

25 De ese modo la ANAC también modificaba el acto legislativo 01 aprobado por el Congreso de la República en 1952, que recordemos había limitado la competencia de ese órgano constituyente. Con esta reforma la ANAC sustituía al Senado de la República. Acto legislativo 1 del 18 de junio de 1953. Diario Oficial No. 28329, Bogotá, 24 de octubre de 1953. 
manifiesta que comparte en su integridad el programa de gobierno que ha presentado al pais (...) ${ }^{26}$

Pero las tensiones entre la Corte y el gobierno de Rojas surgieron al poco tiempo. El enfrentamiento se hizo notorio luego de que quedara en libertad el mencionado ciudadano antioqueño, Felipe Echavarria, por orden del juez Primero del Circuito Penal, Rafael Rocha Riaño, el 4 de noviembre de 195327. Según informes de prensa, el auto de detención bajo el cual Echavarría estuvo privado de su libertad por cinco meses fue revocado: "Por no tener respaldo probatorio y carecer de estructura probatoria”. ${ }^{28}$ Tan pronto el gobierno se enteró de la decisión judicial el Ministro de Justicia, Antonio Escobar Camargo, anunció públicamente la propuesta del gobierno para reformar la justicia. Escobar, quien no hizo referencia al caso Echavarría, expresó que esta se llevaría a cabo mediante reformas constitucionales que se propondrian a la ANAC, reformas legales y decretos extraordinarios que dictaría el Ejecutivo. De manera breve, este fue el diagnóstico que hizo de la justicia que hizo el ministro Escobar en su declaración del 5 de noviembre de 195329:

Sin duda alguna la rama jurisdiccional del poder público, tanto en su composición como en su funcionamiento, se ha mantenido al margen del progreso del país. Esta quietud en la organización judicial ha debilitado la eficacia de la justicia, con perjuicio de la marcha ordenada de la república. La nación sufre claros quebrantos si no hay constante ejercicio de la justicia, si sus decisiones no se pronuncian con la debida prontitud o si es tardío o inoperante su cumplimiento (...) La crónica judicial de Colombia está llena de procesos demorados, interminables, que no pueden desatarse porque los hilos del procedimiento enredan la acción y alargan los incidentes para fatigar y cansar a los litigantes y para retardar el pronunciamiento de un fallo que lleva quebrantado y tardio (...).

La parálisis judicial ha traído la desconfianza de las gentes en la administración de justicia. Grave ocurrencia en una nación joven, espiritualista y respetuosa de la autoridad. Si los jueces pierden la fe de las gentes, carecen de la eminencia social que debian tener: Pero también ellos son víctimas de una organización que tienen el deber de respetar, y que no les permite ser prontos y justos. Así la judicatura ha venido perdiendo mucho de su respetabilidad tan necesaria para la seguridad social y para la tranquilidad de las personas.

26 Comunicación del presidente de la Corte Suprema de Justicia dirigida a la Presidencia de la República el 15 de junio de 1953, citada por: William Freddy Pérez, El sistema penal y la emergencia en Colombia. Scripta Nova. Revista Electrónica de Geografia y Ciencias Sociales 45, 1999.

27 Según refiere James D. Henderson: "Rojas había retirado al juez del circuito Rafael Rocha por anular la condena de Felipe Echavarria". James D. Henderson, La modernización en Colombia: los años de Laureano Gómez, 1889-1965. Op. Cit. P. 539.

28 "Quedó en libertad Incondicional el Señor Felipe Echavarría", El Tiempo, 5 de noviembre de 1953. P. 1 y 19.

29 "Reforma Judicial propone al País el Ministro del Ramo, Escobar C.", El Tiempo, 6 de noviembre de 1953, P. 1 y 15. 
En cuanto a la impunidad, que según el gobierno reinaba en el país, Escobar expresó que esta se debía a las "extrañas ocurrencias que se suscitan en el procedimiento penal, a la presencia de sistemas coloniales que entraban el curso natural de los juicios, a la pesadumbre de fórmulas sacramentales", que los procesos penales no conducian sino a la inoperancia de la justicia criminal de modo que "el delito prospera entre los pliegues de los voluminosos expedientes" e incluso recordó que "La Corte Suprema de Justicia fue impotente ante el urgido y angustioso llamamiento que sobre tales anomalias personalmente le hizo un Presidente de Colombia"30.

Ante tal situación de la justicia en Colombia, el gobierno del general Rojas Pinilla por conducto del ministro Escobar proponía modificaciones a las reglas del proceso penal y al diseño institucional de la rama judicial, que incluía cambios en la Corte Suprema de Justicia, el Consejo de Estado, la jurisdicción del trabajo y la justicia penal, y reformas al Ministerio Público ${ }^{31}$.

En cuanto a la Corte Suprema de Justicia, el gobierno se proponía acabar con la "interinidad" de los magistrados pues estos habían sido nombrados por el presidente Mariano Ospina Pérez mediante decreto de estado de sitio en 1950 debido a que el Congreso, a quien según la Constitución correspondía su designación de ternas propuestas por el Ejecutivo, habia sido cerrado por el mismo Ospina en 1949. Según el gobierno, la designación de los magistrados de la manera ordenada por la Constitución permitía una injerencia perniciosa de la política en la justicia que se solucionaría si el Presidente de la República tenía la "responsabilidad histórica y moral de seleccionar un personal de Magistrados probos y brillantes", para períodos constitucionales que no debían coincidir con el período presidencial. De igual modo, en criterio del Ejecutivo los magistrados no debían ser elegidos teniendo en cuenta una "tarifa de condiciones o una escala burocrática, sino en virtud de una aureola de probidad y de sabiduría" pues "lo mismo puede circundar la cabeza de un veterano de la judicatura o el ejercicio profesional, que la de un ciudadano ilustre que no haya trajinado por estos campos, pero que esté revestido de autoridad jurídica y moral". Además, según el ministro Escobar si la Constitución no exigía al Presidente de la República una carrera burocrática previa, ese mismo criterio debía adoptarse para elegir magistrados de la Corte Suprema de Justicia: "la Iglesia, que es fuente de sabiduría y de gobierno, tiene consagrado este sistema en su organización jerárquica. No será, pues necesaria, para ser Magistrado de la Corte Suprema, condición distinta de una edad determinada y comprobada sabiduría". ${ }^{32}$ Por último, consideraba que la

30 Es probable que se refiera a la reunión urgente convocada por el presidente Laureano Gómez del 13 de abril de 1951, cuando le solicitó al pleno de la Corte medidas para combatir la impunidad luego de varios fallos absolutorios que dictó la justicia penal y con los que Gómez no estuvo de acuerdo. Mario Alberto Cajas Sarria, La Historia de la Corte Suprema de Justicia, 1886-1991, Tomo I: De la Regeneración al régimen militar, 1886-1958. ob. cit.

${ }^{31}$ La reforma judicial: Conferencia del señor Ministro de Justicia, doctor Antonio Escobar Camargo, dictada el 5 de noviembre de 1953, Bogotá, Imprenta Nacional, 1953.

32 Ibíd. 
Corte no debía ser juez de los actos del gobierno, ni siquiera de los decretos "con contenido de leyes dictados en circunstancias excepcionales"33.

La reforma también proponía que la jurisdicción del trabajo fuera absorbida por la rama jurisdiccional de modo que esta se integrara a las Salas de la Corte Suprema y los tribunales y se crearan jueces de circuito del Trabajo. En cuanto a la justicia penal, solo los Jueces de Instrucción Criminal, dependientes del Ministerio de Justicia, llevarian a cabo las investigaciones penales y se reformaría el procedimiento penal para hacerlo más ágil con "investigación escrita en el sumario y el trámite oral en el juicio", que: "harian eficiente la justicia y conducirian a un término equidistante entre el sistema anglosajón de la oralidad penal y el viejo método francés escrito y libre". ${ }^{34}$ En cuanto al Consejo de Estado, el Presidente de la República designaría a todos los magistrados. Por último, los jueces de circuito pasarian a ser nombrados directamente por la Corte Suprema, al igual que los magistrados de los Tribunales Superiores de los Distritos Judiciales de todo el país.

Como se puede apreciar, por un lado la iniciativa del gobierno apuntaba a concentrar un gran poder en la Corte Suprema de Justicia pues a esta se adscribiría el Tribunal Supremo del Trabajo y a ella correspondería el nombramiento de magistrados de Tribunales y de jueces de circuito. Pero como Rojas nombraría tanto a los magistrados de la Corte como a los del Consejo de Estado, el Ejecutivo se hacía al control de la rama judicial. A esto se suma que el gobierno militar mostraba su deseo de tener su propio juez constitucional, pues como veremos en el siguiente apartado la reforma proponía crear un Tribunal de Garantías Constitucionales que ejercería el control constitucional en reemplazo de la Corte Suprema de Justicia.

Si bien hubo voces encontradas sobre las bondades de la reforma judicial, lo cierto es que el pico de la crisis entre el Ejecutivo y la rama judicial llegó con el pronunciamiento del general Rojas en Cartagena el 11 de noviembre de 1953, cuando acusó a la rama judicial de estar politizada, de actuar por móviles partidistas y de no estar a la altura de los cambios que requería el país ${ }^{35}$. En buena parte, la reacción de Rojas en contra del poder judicial se debía a la mencionada decisión del juez penal de dejar en libertad a Felipe Echavarría. Según el general, en el curso del proceso judicial llegaron numerosas informaciones a la Presidencia de la República que daban cuenta de las presiones a la justicia para resolver el caso a favor de Echavarría, aunque el gobierno no había querido intervenir en el asunto. Rojas, muy inconforme con la decisión judicial, señaló36:

33 Ibíd.

34 "Reforma Judicial propone al País el Ministro del Ramo, Escobar C.", El Tiempo, 6 de noviembre de 1953, P. 1 y 15.

35 "Paz, Justicia, Libertad, postulados invariables del actual Gobierno: trascendental discurso del Presidente en Cartagena". El Tiempo. 12 de noviembre de 1953, 1 y 14.

36 Ibíd. P. 14. 
Aislada y personalmente el caso del señor Echavarría no tiene mayor importancia, pero viene a comprobar la imperiosa necesidad de que los funcionarios judiciales sean escogidos y probados por sus antecedentes morales y su capacidad profesional, a fin de que la administración de justicia no sea desprestigiada por la ignorancia o envilecida por el dinero, ni mucho menos por las interferencias partidistas, porque, como decía un gran moralista, "entre la política y la justicia toda inteligencia es corruptora y todo contacto es pestilencial"

De este modo, el caso Echavarría servía de marco para mostrar la necesidad de la "profunda" reforma judicial anunciada por el ministro Escobar una semana antes y que luego el propio general Rojas se encargó de reiterar en su discurso del 11 de noviembre de 1953. Este sería el primer conflicto del gobierno militar luego de varios meses de júbilo nacional por su llegada al poder ${ }^{37}$.

\subsection{El general Rojas Pinilla propone un Tribunal de Garantias Constitucionales para Colombia}

En la propuesta de reforma judicial del general Rojas de 1953 aparecía el Tribunal de Garantías Constitucionales (en adelante, TGC). Con él, como se dijo, se trataba de poner fin a la función de juez constitucional que desempeñaba la Corte Suprema de Justicia desde la reforma constitucional del acto legislativo 03 de 1910. La propuesta dejaba ver la incomodidad del gobierno militar con este papel de la Corte, aun cuando el ministro Escobar hiciera todo lo posible por justificar la iniciativa como una "necesaria reforma" para "tecnificar" la justicia constitucional colombiana. La defensa judicial de la constitución era una cuestión sensible para el Ejecutivo pues recordemos que la Corte tenía la función de juzgar la constitucionalidad de las leyes y algunos decretos, como los dictados por el gobierno en ejercicio de las facultades constitucionales del estado de sitio, y precisamente el general Rojas ejercía el poder a través de estas herramientas legales ${ }^{38}$. Así justificó el ministro Escobar la reforma en su declaración del 5 de noviembre de 195339:

No hay razón técnica que haga necesario conferir a la cabeza de la Rama Jurisdiccional la facultad de decidir sobre la validez de los actos del Congreso y del Gobierno. Además de que coloca al Gobierno y al Congreso en situación de

37 Según Álvaro Tirado, la Corte sintió que Rojas afectaba la tradicional independencia del tribunal. Álvaro Tirado. "Rojas Pinilla: del golpe de opinión al exilio". En Nueva Historia de Colombia: Historia Politica, 1946-1986, Planeta, Bogotá, 1989. Pp. 105-126.

38 Para un análisis de la jurisprudencia de la Corte Suprema de Justicia sobre los decretos de estado de sitio y las reformas constitucionales bajo el régimen militar, véase: Mario Alberto Cajas Sarria, La Historia de la Corte Suprema de Justicia, 1886-1991, Tomo I: De la Regeneración al régimen militar, 1886-1958, op. cit.

39 La reforma judicial: Conferencia del señor Ministro de Justicia, doctor Antonio Escobar Camargo, dictada el 5 de noviembre de 1953, op. cit. P. 13. 
inferioridad, convierte a la Corte Suprema de Justicia en árbitro de las otras Ramas del Poder (...), y adscribe a sus Magistrados una modalidad del Derecho Público que no es de su competencia. Jueces dedicados a la técnica de casación carecen de suficiente experiencia para juzgar la exequibilidad de sus actos que deben ser resueltos y analizados a la luz del Derecho Público.

La propuesta del gobierno consistía en asignar al TGC el estudio de "la exequibilidad de las leyes y los decretos con fuerza de ley". Este nuevo órgano se integraria por los presidentes de las Salas de la Corte Suprema de Justicia, por los presidentes de las Salas del Consejo de Estado y por tres representantes del Presidente de la República. Es decir que todos sus magistrados serían nombrados por el Ejecutivo pues recordemos que en la reforma judicial se proponía que los magistrados de la Corte Suprema y del Consejo de Estado serían designados por el Presidente de la República.

Como se observa, la reforma apuntaba a resolver dos problemas del modelo vigente: el "déficit técnico" de la justicia constitucional en cabeza de la Corte y la influencia política en los fallos. Esta última era tal vez la que más dominaba la percepción de la opinión pública. A modo de ejemplo se pueden mencionar dos de esas decisiones controversiales: la sentencia de la Corte, que integrada mayoritariamente por magistrados de origen Liberal, declaró exequibles las medidas de estado de sitio del gobierno del también liberal Alfonso López Pumarejo, contra el que se habia intentado un golpe militar en la ciudad de Pasto en 1944, bajo las cuales se habia juzgado y condenado a varios militares y perseguido a civiles que integraban el partido Conservador; o el fallo de 1949 en el que la Corte de mayorías liberales declaró infundadas las objeciones presidenciales de Mariano Ospina Pérez a un proyecto de ley aprobado por un Congreso mayoritariamente liberal que acortaba el período de gobierno y convocaba a elecciones anticipadas, en pleno enfrentamiento bipartidista. Estas decisiones, ligadas al origen partidista de los magistrados de la Corte, quienes según la Constitución eran elegidos por el Congreso de ternas propuestas por el Presidente de la República para períodos de 5 años pudiendo ser reelegidos indefinidamente, hacian que se percibiera a la corporación como un órgano politizado que actuaba con criterios facciosos dependiendo de las fuerzas políticas que dominaran el Congreso y el Ejecutivo ${ }^{40}$.

Aunado a lo anterior, los reclamos en contra de la Corte también pasaban por la morosidad de sus fallos en juicios de constitucionalidad pues incluso hubo algunos que duraron pendientes de decisión hasta 14 años, como narra Carlos Restrepo Piedrahita sobre la demanda de Luis E. Nieto Arteta contra dos decretos de 1940. En palabras de Restrepo: "La acción popular fue- y sigue siendo- apenas saltuariamente utilizada por los ciudadanos y la Corte Suprema se comportaba displicentemente morosa para decidir la demandas de inexequibilidad" 41.

\footnotetext{
40 Mario Alberto Cajas Sarria, La historia de la Corte Suprema de Justicia de Colombia, 18861991, Tomo I. ob. cit.

41 Carlos Restrepo Piedrahita. Tres ideas constitucionales: Supremacía de la Constitución, Corte Constitucional, El Ombudsman. Universidad Externado de Colombia, Bogotá, 1978. P. 65.
} 
Es importante señalar que tanto los vientos de reforma al modelo de justicia constitucional como la iniciativa de crear un Tribunal de Garantias ya soplaban unos años antes de la iniciativa del gobierno militar. Por ejemplo, con motivo de la propuesta de 1953 el jurista de origen conservador Arturo Tapias Pilonietta recordó que cuando fue Ministro de Justicia en 1947 propugnó "por el establecimiento de este tribunal" pues creía que: "la guarda de la Constitución debe tener un Tribunal especial elegido no por el Congreso sino por otro sistema que asegure su independencia"42.

De igual modo, a comienzos de la década de los cincuenta hubo voces académicas críticas al sistema de control constitucional local, como por ejemplo la del profesor Eustorgio Sarria, quien propuso reformar el modelo constitucional vigente. Según Sarria, la facultad que tenía la Corte Suprema de Justicia de declarar la exequibilidad de las leyes y decretos era, "un privilegio exorbitante que no armoniza con un régimen realmente democrático", pues no podia, "colocarse a una rama del Poder Público por encima de las otras ni mucho menos de la que tiene como función esencial legislar"43. Tal función, decía el profesor, era: "un remedo de la consignada en la constitución saxoamericana de 1787, y en la forma como está concebida es inadmisible"44. A esto se sumaba la regla constitucional de que "en caso de incompatibilidad entre la ley y la Constitución” debía aplicarse de preferencia la segunda con lo cual según Sarria: “(...) cualquier funcionario público, magistrado, juez, alcalde o corregidor, decide para un determinado caso por vía de excepción, sobre asunto de tanta monta, de suyo delicado y complejo ${ }^{45}$. De igual modo, acusaba al modelo vigente de contribuir a la politización de la "rama jurisdiccional"46. En palabras del profesor: "La experiencia enseña a los colombianos que en los casos con trascendencia la Corte ha sido victima de las intrigas o acometidas sectarias. Ya no se le demanda un concepto o un fallo de real contenido juridico, sino de inmediata utilidad

${ }^{42}$ La reforma judicial: Conferencia del señor Ministro de Justicia, doctor Antonio Escobar Camargo, dictada el 5 de noviembre de 1953, op. cit. P. 19.

43 Eustorgio Sarria: Tratado de Derecho Administrativo, segunda edición, Crítica Jurídica, Bogotá, 1952. P.46.

44 Ibíd.

45 Ibíd. P. 46

46 Es oportuno mencionar que Eustorgio Sarria era un jurista de profundas convicciones liberales y por tanto no se debe descartar que su opinión sobre el sistema constitucional vigente en parte también haya estado influenciada por su percepción sobre el papel que jugaba la Corte Suprema de Justicia bajo el gobierno de Laureano Gómez (1950-1953), pues la corporación había sido conformada por decreto de estado de sitio en 1950 y era vista como un órgano obsecuente con el Ejecutivo. La férrea postura de Sarria en contra del régimen conservador se aprecia en la introducción de la segunda edición del libro que acabamos de citar en donde expresó que se vivía una "crisis del Estado de Derecho en los actuales momentos (de la cual saldrá victorioso y vigorizado)", que su obra era una "contribución intelectual a la perentoria defensa de la democracia y al repudio de todo régimen de poder", y que su "modesto tratado" buscaba "avivar la fe en el derecho y la justicia". op. cit. 
Mario Alberto Cajas Sarria

politica"47. Por todas estas razones estimaba que era urgente acometer una reforma que sustituyera a la Corte Suprema de Justicia por un Tribunal de Garantias Constitucionales (TGC), bajo esta fórmula ${ }^{48}$ :

Toda ley se presume constitucional a menos de declaración expresa en contrario del tribunal de garantias constitucionales hecha de oficio o a solicitud de cualquier funcionario público, persona natural o jurídica.

En casos de excepcional gravedad, y mientras se pronuncia un fallo de definitivo, el mismo Tribunal puede disponer la aplicación general de la ley.

Para Eustorgio Sarria el mencionado TGC "podría organizarse en forma semejante a la establecida en la constitución española de 1931, artículo 121: con jurisdicción en todo el territorio nacional e integrado por sendos representantes de las ramas del poder público y dos representantes de las facultades de derecho". En su criterio, "un tribunal integrado por representantes auténticos de las diferentes ramas del poder público y de la ciencia juridica, si constituye una garantía de acierto" pues: "Los principios de la Constitución no son, no pueden ser inertes, rígidos, sino por el contrario sensibles a la evolución social" y por tanto "a su interpretación deben concurrir quienes hacen la ley, la aplican, la enseñan y por ello mismo piensan y obran de modos no opuestos, pero si disimiles"49.

\footnotetext{
47 Alvaro Copete Lizarralde, constitucionalista ex Procurador General de la Nación (1951-1953) y luego integrante de la Comisión de Estudios Constitucionales en tiempos del general Rojas (1954), respondió a las objeciones de Sarria argumentando que ninguna de ellas justificaba sustituir a la Corte Suprema de Justicia por otro órgano de justicia constitucional. Por ejemplo, a la objeción de que la Constitución ponía a la "rama jurisdiccional" por encima de la legislativa" respondió que en el derecho moderno había una "rectificación" del principio de separación de poderes pues la revisión constitucional de las leyes necesariamente hacía que el órgano de control constitucional estaría "por encima de la rama legislativa". De igual modo señaló que de ninguna manera se desnaturalizaba la función de la Corte cuando se le asignaba la facultad de decidir sobre la exequibilidad de las leyes y recordó que aún en Francia, en donde antes de la Constitución de 1946 no existía norma sobre el control de "leyes inconstitucionales", los tribunales no aplicaron "leyes que habia sido expedidas con pretermisión de las formalidades de la Constitución, decidiendo, por tanto, sobre la llamada inconstitucionalidad formal". Para esto incluso citó autores franceses como Duguit, Hauriou y Renard, que a su modo de ver, "fortifican nuestra opinión sobre la conveniencia del sistema judicialista en materia de la guarda de la Constitución, puesto que provienen de un país en donde la Constitución no ha dado, ni expresa ni tácitamente, facultad a los jueces para decidir sobre la excepción de inconstitucionalidad". Por último, aunque coincidió con Sarria en la crítica a la influencia política en los fallos de la Corte Suprema, no eran un problema de la Corte sino del país y nada se haría con cambiar de tribunal pues nada haria que sus integrantes se sustrajeran de las influencias politicas. En particular, sobre la idea de crear un TGC a la manera del español, Copete recordó que la ley aprobada por las Cortes el 30 de junio de 1933 amplió el TGC de ese país a 26 miembros de modo que, "no es menester hacer comentario a la inconveniencias de un tribunal tan numeroso." Álvaro Copete Lizarralde. Lecciones de derecho Constitucional. 1957. Bogotá: Temis, segunda edición. P. 253257.
}

48 Eustorgio Sarria: Tratado de Derecho Administrativo, op. cit. P.46.

49 Ibíd. P. 47. 
Regresando a la propuesta del general Rojas Pinilla de crear un TGC en 1953, esta parecía coincidir con las voces que criticaban el sistema de justicia constitucional vigente y que habían propuesto cambios al mismo. Pero si bien había razones para hacer ajustes al modelo, lo que no parecía muy convincente era la solución "técnica" propuesta por el gobierno militar de suprimir el control constitucional de la Corte Suprema de Justicia para confiarlo al TGC. Primero, porque si bien el nuevo tribunal podría liberar al pleno de la Corte de la "carga" de los juicios de constitucionalidad para así descongestionarla y ganar celeridad en los procesos de constitucionalidad, recordemos que la nueva corporación estaría integrada en su mayoría por los magistrados presidentes de las Salas del Consejo de Estado y de la Corte Suprema, es decir por magistrados activos en sus respectivas corporaciones que también debian seguir cumpliendo con las responsabilidades propias de sus cargos en esas altas Cortes. Además, porque en el diseño institucional propuesto la "cuota" de derecho público del TGC provendría de los tres Consejeros de Estado que lo conformarian, pues los magistrados de las Salas de la Corte Suprema eran casacionistas, y por supuesto la posible contribución de iuspublicistas que decidiera nombrar el propio general Rojas Pinilla, quien designaría a su arbitrio tres miembros del TGC.

Así las cosas, la iniciativa de Rojas de crear un Tribunal de Garantías Constitucionales para reemplazar a la Corte Suprema como juez constitucional dejaba ver su trasfondo político: el Ejecutivo quería tomar el control de la justicia constitucional.

\section{4. ¿El Tribunal de Garantias Constitucionales de España viaja a Colombia?}

El Tribunal de Garantías Constitucionales (TGC) que proponía el régimen militar para la Colombia de 1953 surgía en la segunda posguerra. Es decir en la época en que empezaba a expandirse por Europa el modelo de control constitucional concentrado propuesto por Hans Kelsen ${ }^{50}$, según el cual se confiaba a un tribunal especializado e independiente la defensa de la Constitución y el control de constitucionalidad de las leyes ${ }^{51}$, que se inaugura con el Tribunal Constitucional de Checoslovaquia $^{52}$ y la Alta Corte Constitucional de Austria en 192053. Fuertemente

50 Boris Mirkine Guetzevitch, Modernas Tendencias del Derecho Constitucional, Traducción del francés por Sabino Álvarez, Madrid, Editorial Reus, 1934.

51 Luís Cervantes, Los tribunales constitucionales en el derecho comparado: Un estudio introductivo sobre sus antecedentes y situación jurídica actual, Estudios básicos de Derechos Humanos, VI. San José, IDH, 1996. P. 358.

52 Pedro Cruz Villalón, "Dos modos de regulación del control de constitucionalidad: (Checoslovaquia (1920-1938) y España (1931-1936). Revista Española de Derecho Constitucional Año 2, Número 5, Mayo-agosto 1982. Pp. 115-148.

53 Un interesante análisis del contexto histórico y político del surgimiento del Tribunal Constitucional austriaco y los esfuerzos de Kelsen para establecerlo en: Sara Lagi, "Hans Kelsen and the Austrian Constitutional Court", 1918-1929, Revista Co-herencia, Vol 9, No. 16, enero-junio, 2012. Pp.273-295. 
inspirados en el diseño kelseniano primero se creó el Tribunal de Garantías Constitucionales ${ }^{54}$ en la Constitución española de la II República el 9 de diciembre de $1931^{55}$ y se instaló el 20 de octubre de $1933^{56}$. Luego en la posguerra se creó el Tribunal Constitucional de Italia en la Constitución del 21 de diciembre de 1947, que inició funciones en $1956^{57}$. Por último, el Tribunal Constitucional alemán que se estableció en la Ley Fundamental de 1949 y empezó a funcionar luego de la expedición de la Ley del Tribunal Constitucional en 1951.

Ahora bien, como se sabe, en el caso de Colombia para la década del cincuenta del siglo XX si bien no se había establecido un sistema de control constitucional concentrado con un tribunal como los mencionados, desde la reforma constitucional de 1910 se había atribuido a la Corte Suprema de Justicia la facultad de declarar la inconstitucionalidad de las leyes mediante la acción pública de inconstitucionalidad. Es decir que en el contexto local había un mecanismo judicial mediante el cual cualquier ciudadano podia demandar las leyes ante la Corte Suprema, lo que permitía un amplio acceso a la justicia constitucional, aun cuando el sistema de control de constitucionalidad no era tan "técnico" pues la Corte era un tribunal de casación integrado por civilistas y penalistas más no por juristas formados en derecho público. De este modo, la propuesta de establecer un Tribunal de Garantias Constitucionales parecía mirar hacia Europa en busca de un modelo que

\footnotetext{
${ }^{54}$ Esa influencia se puede apreciar en la cita que reproduce Eduardo Ferrer Mac Gregor de Niceto Alcalá Zamora, quien narra cómo hubo un influjo directo de las ideas de Hans Kelsen y el Tribunal Constitucional austriaco de 1920 en el Tribunal de Garantías Constitucionales de España y señala que tal jurisdicción constitucional "incluso coincide con el nombre que en principio se le dio a la nuestra: Tribunal de Justicia Constitucional, luego cambiado por la Comisión Parlamentaria por la denominación vigente, quizás para emplear una rúbrica que refleje mejor lo complejo de su cometido.", Eduardo Ferrer Mac Gregor, "Niceto Alcalá Zamora y el derecho procesal constitucional", Panorámica del Derecho Procesal Constitucional, 2013, México D.F: Marcial Pons- UNAM. P. 128 La cita corresponde al trabajo de N. Alcalá al cual se atribuye la fundación del derecho procesal constitucional hispanoamericano: Significado y funciones del Tribunal de Garantías Constitucionales, Editorial Reus, Madrid, 1933.
}

55 La bibliografia sobre la influencia del modelo Kelseniano en el Tribunal de Garantías Constitucionales de 1931 es amplia. Entre otros véanse el mencionado texto de Niceto Alcalá Zamora: "Significado y funciones del Tribunal de Garantías Constitucionales", también: Francisco Rubio Llorente "Del Tribunal de Garantías al Tribunal Constitucional" Revista de Derecho Politico No. 16, Invierno, 1982-1985; José Luis Cascajo Castro: "Kelsen y la Constitución española de 1931", Revista de Estudios Políticos No. 1 (Nueva Época), Centro de Estudios Políticos y Constitucionales, Madrid, 1978. Pp. 243-256; Héctor Fix- Zamudio, Los Tribunales Constitucionales y los Derechos Humanos, 1980, México, D.F: UNAM. Por último, José F. Palacio Manchego: "Los orígenes de los Tribunales Constitucionales en América Latina", en: El derecho público a comienzos del siglo XXI: estudios en homenaje al profesor Allan R. Brewer Carías, Alfredo Arismendi y A., Jesús Caballero Ortiz (Coord.) Vol. 1, Madrid: Civitas, 2003. PP. 1015-1027, que además ofrece una amplia referencia bibliográfica sobre los debates constituyentes previos a 1931 y todo lo relativo al tribunal.

56 José F. Palomino Manchego: "Los orígenes de los Tribunales Constitucionales en América Latina", op. cit. P.12

57 Mauro Cappeletti, "La justicia constitucional en Italia", en: XIII Boletín del Instituto de Derecho Comparado de México 41, traducción de Héctor Fix- Zamudio, UNAM México, D.F, 1960. 
"remediara" las falencias locales, pero ocultaba las fortalezas de una trayectoria institucional propia.

Es probable que el proyecto del TGC del general Rojas recogiera elementos de la propuesta del iuspublicista Eustorgio Sarria, que decia inspirarse en la constitución española de 1931. Sin embargo el proyecto del gobierno militar difería tanto de la iniciativa de Sarria como del modelo español. En efecto, era distinto a la de Sarria porque recordemos que él planteaba la integración del tribunal con representantes de las tres ramas del poder público y de las facultades de derecho. Por otra parte, difería del TGC español de $1931^{58}$ que no pertenecía a la rama judicial y estaba compuesto por veintiséis miembros ${ }^{59}$, entre ellos los presidentes del Consejo de Estado y del Tribunal de Cuentas, además los otros vocales eran electivos e incluso a algunos no se les exigía ser abogados ${ }^{60}$.

Ahora bien, la posible influencia en Colombia de la experiencia del TGC de la Constitución de la II República española de 1931 es de gran interés y amerita una exploración que desborda los propósitos de este trabajo, sin embargo es oportuno referirse brevemente a algunos factores que podrian explicar el protagonismo del modelo español. En primer lugar, no se puede dejar de lado que aquel fue uno de los primeros tribunales constitucionales establecidos para la defensa de la constitucionalidad de las leyes en Europa y por tanto en su momento era considerado una novedad61. No obstante, lo llamativo era que se tuviera en cuenta un modelo que había tenido un vida tan corta pues para el año 1936 había sucumbido con la llegada al poder del general Francisco Franco, además porque el TGC se habia caracterizado por su poca eficacia para ejercer el control constitucional pues se había politizado en extremo. ${ }^{62}$ Sobre esto último la opinión

58 Para un interesante estudio sobre las doctrinas del derecho constitucional desde la perspectiva de los memorias de cátedra de los tres principales constitucionalistas de la II República española, véase: Sebastián Martín, El derecho politico en la segunda república: Francisco Ayala, Eduardo L. Llorens y Nicolás Pérez Serrano, Estudio preliminar, edición y notas de Sebastián Martin, Universidad Carlos III de Madrid- Dykinson, Madrid, 2011

59 Francisco Rubio Llorente, "Del Tribunal de Garantías al Tribunal Constitucional", Revista de Derecho Político No. 16, Invierno, 1982-1985. P. 31.

60 "El Tribunal de Garantías Constitucionales estaba integrado por veintiséis miembros de heterogénea extracción sociopolítica. Así, el presidente elegido por el Congreso y los veinticinco vocales eran un grupo misceláneo formado por el presidente del Alto Cuerpo Consultivo de la República, el presidente del Tribunal de Cuentas (vocales natos), dos diputados designados por la propia Cámara, un representante de cada una de la Regiones españolas, sean autónomas (Cataluña) o no, dos miembros nombrados por los Colegios de Abogados y cuatro profesores de la Facultad de Derecho de las universidades españolas (vocales electivos) (artículo 122 de la Constitución).” Héctor Álvarez García, "La naturaleza politica del Tribunal de Garantías Constitucionales de la segunda república española" Revista de Derecho Político, UNED, No. 80, enero-abril 2011, P.194.

61 Sobre las innovaciones de la Constitución española de 1931 y algunas de sus influencias, véase: Javier Corcuera Atienza, "La Constitución española de 1931 en la historia constitucional comparada", en: Fundamentos: Cuadernos monográficos de teoría del estado, derecho público e historia constitucional, No. 2, 2000. Pp. 626-695.

62 Héctor Álvarez García, "La naturaleza política del Tribunal de Garantías Constitucionales de la segunda república española”. op. cit. 
del profesor español Héctor Álvarez García arroja luces acerca la naturaleza del Tribunal63:

\begin{abstract}
El frontal rechazo de las constituyentes y de los legisladores a entregar el control de constitucionalidad al cuerpo de juristas, como hubiera sido lo deseable, nos revela la firme determinación de politizar el Tribunal de Garantías -cuya naturaleza y altas funciones no llegaron a ser entendidas por muchos de los parlamentarios que lo identificaban con un sucedáneo del fallido Senado- para influir en el sentido de las sentencias, al preponderar la filiación política sobre la formación jurídica en sus miembros, lo que sepultó institucionalmente al Tribunal porque lo convirtió en un campo más en el que librar la mezquina batalla partidista por el Poder.
\end{abstract}

En línea con Álvarez, afirma José F. Palomino Manchego64: "En total, encajaban en su estructura 26 miembros! (número par), muchos de ellos ajenos a la magistratura, $y$, por ende, ajenos a la realidad juridica que es justamente de lo que más se preocupó Hans Kelsen cuando diseñó el Tribunal Constitucional de Austria"65, pues "El mentor de la Teoría Pura del Derecho trató de apartar a los magistrados constitucionales de la politica-stricto-sensu", y agrega: "Se desprende de lo expuesto que la misma composición que tenia el TGC no garantizaba su funcionamiento eficaz e independiente ya que, conforme se aprecia, existian miembros que podian actuar como juez y parte, por ejemplo los diputados"66

Pero si bien la experiencia española no parecía muy afortunada para finales de los años cuarenta e inicios de los cincuenta, veamos otros factores que también podrían explicar esa posible influencia en Colombia: sin duda hay que considerar la cercanía lingüística y la familiaridad cultural del derecho colombiano con España. Asimismo, como los tribunales italianos y alemanes apenas se instalaban a comienzos de los años cincuenta es probable que su prestigio no fuera tan amplio en América Latina, a lo cual se podría sumar la baja legitimidad de nuevas instituciones creadas por dos paises que acababan de ser derrotados en la Segunda Guerra Mundial y apenas se recuperaban de sus respectivas dictaduras. Por último, otro elemento que pudo haber contribuido a la notoriedad de la experiencia española es la difusión del modelo del TGC por doctrinantes españoles, como Niceto Alcalá-

63 Ibíd. P. 200.

64 José F. Palomino Manchego: “Los orígenes de los Tribunales Constitucionales en América Latina". op. cit. P.15.

65 Ibíd.

66 En el mismo trabajo del profesor Palomino, del cual se extrae la cita precedente sobre el TGC español, se abordan los intentos de instaurar una Corte Constitucional en Colombia y en ellos no se registran propuestas previas a la de 1968; la ausencia es comprensible porque en la academia colombiana el canon de la trayectoria del Tribunal Constitucional suele situarse en la reforma constitucional de 1968. De ahí la necesidad de explorar antecedentes como el de la justicia constitucional del general Rojas e incluso unos años atrás. 
Zamora, quien antes y durante su exilio en Latinoamérica publicó varios textos sobre jurisdicción constitucional y "derecho procesal constitucional", que fueron ampliamente conocidos en varios países de la región entre los años cuarenta y sesenta67.

Para terminar, si bien los modelos colombianos de TGC parecen inspirarse en la experiencia española valdría la pena explorar su posible relación con el Tribunal de Garantías Constitucionales y Sociales establecido en Cuba con la reforma constitucional de $1940^{68}$, ese órgano, que realmente era una de las salas del Tribunal Supremo de Justicia69, habría sido el primero de América Latina en establecerse según el modelo de tribunal constitucional europeo de tipo concentrado, e inspirado, -al menos en nombre-, en el Tribunal de Garantías Constitucionales de España de $1931^{70}$.

\subsection{Las voces sobre la reforma: crisis judicial}

Varios reconocidos juristas de la época expresaron sus opiniones favorables al proyecto de reforma del gobierno del general Gustavo Rojas Pinilla. Por ejemplo, aunque no se refirió expresamente a la creación del Tribunal de Garantías Constitucionales, el ex ministro liberal y decano de Facultad de Derecho de la Universidad Libre de Colombia, Julio Roberto Salazar Ferro, manifestó estar de acuerdo con las iniciativas del gobierno. Por su parte, el presidente del Consejo de Estado, Manuel Dangond Daza señaló ${ }^{71}$ :

67 Eduardo Ferrer Mac Gregor: "Niceto Alcalá Zamora y el derecho procesal constitucional", Panorámica del Derecho Procesal Constitucional, 2013, México D.F: Marcial Pons- UNAM. Pp. 129130.

68 Sobre la trayectoria del control constitucional en Cuba puede verse: Andry Matilla Correa: "El control jurisdiccional en la constitucionalidad cubana de 1901".En: Escritos sobre derecho procesal constitucional, homenaje cubano al profesor Héctor Fix Zamundio en sus 50 años como investigador del Derecho, IIj- UNAM, Universidad de la Habana, La Habana, 2012. P. 169-252.

69 "Por tanto, lo que en rigor existió en Cuba a partir de la Constitución de 1940, era una Sala Constitucional, pero con otro nombre, que era un embrión de tribunal constitucional y que pudo haberlo sido si no hubiera pasado lo que pasó. Pero que sólo llegó a eso. En realidad, lo que consagró la carta de 1940 era una especie de control concentrado en una sala al interior del Tribunal Supremo (y de ahi su gran diferencia con el modelo norteamericano, que es difuso). Y en tal sentido, el caso cubano es un planteamiento original en el tema del control de constitucionalidad, no sólo por lo que avizoró, sino porque creó una figura intermedia, que hoy por hoy tiene su más relevante expresión en la Sala Constitucional que existe en Costa Rica, desde 1989. Y que desde entonces otros paises han imitado". Domingo García Belaunde, "El Tribunal de Garantías Constitucionales y Sociales de Cuba (19401952)". Apéndices, Boletín Mexicano de Derecho Comparado, Vol. XXXVII, número 109, enero- abril de 2004.

70 Ibíd. P. 295. Como señala Domingo Belaunde, esa Sala del Tribunal Supremo ejercía el control de constitucionalidad sobre todo tipo de normas, "sin excepción alguna, y en otras situaciones más".

71 La reforma judicial: Conferencia del señor Ministro de Justicia, doctor Antonio Escobar Camargo, dictada el 5 de noviembre de 1953, op. cit. P. 21. 
Yo participo de las ideas expresadas por el titular de la Cartera de Justicia, en lo que hace relación a las reformas propuestas por él para la Rama Jurisdiccional del poder Público. Felizmente con algunas de esas ideas coincidió el Consejo de Estado al enviar un proyecto de reforma a la antigua Comisión Preparatoria que elaboró un proyecto para ser sometido a la Asamblea Nacional Constituyente. Considero que la justicia de Colombia ganará mucho sí se llevaran a la realidad los prospectos del doctor Antonio Escobar Camargo.

También el ex ministro de Justicia, Arturo Tapias manifestó su opinión favorable a la propuesta de que los magistrados de la Corte Suprema fueran nombrados por el Presidente de la República pero propuso que las magistraturas fueran vitalicias con edad mínima de ingreso a los sesenta años y que las vacantes que se presentaran las proveyera el propio Presidente de la República pero de una lista que podría ser conformada por nombres propuestos por instituciones como las Facultades de Derecho, el Procurador General de la Nación o la Academia Colombiana de Jurisprudencia, todo esto con el fin de evitar la politización del tribunal. En cuanto al TGC, apoyó su creación ${ }^{72}$.

Otto Morales Benítez, destacado dirigente liberal, si bien manifestó su complacencia por la reforma a una justicia que no funcionaba, expresó sus inquietudes porque no se planteaba nada sobre la necesaria carrera judicial. También recordó que el sistema de elección de magistrados de la Corte Suprema había sido asunto de debate en la reforma de 1910 y que allí con espíritu republicano se estableció la participación del Congreso en esas elecciones, lo cual contribuía a evitar que el Ejecutivo afectara la independencia del tribunal. Según Morales era riesgoso dejar en manos del TGC la decisión sobre la exequibilidad de las leyes pues si el Ejecutivo iba a nombrar a los magistrados de las altas Cortes, el Tribunal de Garantías Constitucionales podría quedar bajo el dominio del gobierno ${ }^{73}$.

Por su parte, la Corte Suprema de Justicia más que pronunciarse sobre la propuesta de reforma a la justicia, deliberó por dos intensos dias hasta llegar a la decisión de presentarle al general Rojas la renuncia de todos sus magistrados ante el discurso que este pronunciara el 11 de noviembre. A juicio de la corporación, Rojas había lanzado acusaciones indiscriminadas contra los jueces y la administración de justicia que la llevaban a tomar el camino de dejar sus cargos. Esto dijo la Corte en su carta de renuncia motivada ${ }^{74}$ :

Consideramos, excelentísimo señor, como un debe indeclinable de nuestra parte afirmar categóricamente que, a pesar de los defectos de las instituciones nacionales, los jueces colombianos, principiando por la Corte Suprema de

\footnotetext{
72 Ibíd. P. 20.

73 Ibíd. P. 26.

74 "La Corte renunció ayer por la indiscriminación de cargos." El Tiempo. 14 de noviembre de 1953, P. 15.
} 
Justicia han estado permanentemente revestidos del decoro y dignidad que corresponden al augusto ministerio que desempeñan. Solo por excepción pudieran citarse casos aislados de designaciones equivocadas o de juzgadores que hayan resultado éticamente inferiores a la primordial de las funciones del Estado cual es la de dispensar el derecho y reprimir el delito. Sobre ellos debe recaer implacable la sanción de la ley y pronto habrá de conocerlos la nación según la promesa de su excelencia en Cartagena. Pues no está bien que sigan flotando sobre la integridad de magistrados y jueces las indiscriminadas aseveraciones que alli se hicieron.

Mas como estas aseveraciones colocan a la Corte en una situación excepcionalmente incómoda para seguir administrando justicia, con toda consideración y respeto presentamos a su excelencia renuncia de nuestros cargos, en la esperanza de que esto pueda servirle para la realización de sus programas de gobierno.

Así, aunque la corporación no hizo ningún pronunciamiento sobre la reforma a la justicia recién propuesta por el gobierno del general Rojas, la renuncia se producía en un clima de alta tensión institucional y en donde las declaraciones presidenciales del 11 de noviembre en Cartagena solo eran el punto más alto de la confrontación. Ante la renuncia de la Corte el general Rojas aprovechó para enviar al país un mensaje de concordia y dejar ver el "espíritu" de su gobierno de mejorar la justicia y por eso anunció que integraría de manera paritaria una nueva Corte con magistrados de origen liberal y conservador compuesta75 "por los más renombrados juristas, que por su consagración capacidades experiencias y estudios comprendan en todo instante la altura de su misión, tengan dotes para fallar cuando la ley sea oscura y deficiente y puedan desentrañar los principios tutelares del derecho, las razones para sostener la justicia, sin, que la jurisprudencia se petrifique o vuelva las espaldas a las exigencias de la vida contemporánea"76.

Superada la "crisis judicial", Rojas integró con representación paritaria de los dos partidos políticos la nueva Corte Suprema de Justicia. Los magistrados liberales eran: Carlos Arango Vélez, Manuel Barrera Parra, Aníbal Cardozo Gaitán, Darío Echandia, Roberto Goenaga, Ricardo Jordán Jiménez, Néstor Pineda y Antonio Rocha; y los conservadores, Luis Felipe Latorre, Fernando Londoño, Germán Orozco Ochoa, José J. Gómez, Eduardo Rodríguez Piñeres, Guillermo Salamanca, Alberto Zuleta Ángel y Domingo Sarasty ${ }^{77}$.

75 "Total renovación de la Corte: El Presidente hizo el anuncio en Bucaramanga". El Tiempo. 29 de noviembre de 1953, 1 y 21.

76 Ibíd. 21.

77 Presidencia de la República, Decreto 3110 del 27 de noviembre de 1953, Diario Oficial Año XC, No. 28359, Bogotá, 30 de noviembre de 1954. 
Mario Alberto Cajas Sarria

\section{LA SALA DE NEGOCIOS CONSTITUCIONALES DE 1956: EL LÍMITE AL CONTROL CONSTITUCIONAL DE LA CORTE SUPREMA SE CONCRETA.}

\subsection{La nueva Corte Suprema y el clima de entendimiento con el régimen militar, 1954}

El general Gustavo Rojas Pinilla nombró una Corte Suprema de Justicia integrada paritariamente por magistrados conservadores y liberales, para lo cual contó con el apoyo de las élites políticas respectivas ${ }^{78}$. Rojas posesionó a los nuevos magistrados el 1 de febrero de 1954 y aprovechó para hablar de su "política" sobre la rama judicial y la Corte $^{79}$ :

El gobierno interpreta con fidelidad el sentir del pueblo colombiano, al declarar solemnemente que el acto de vuestra instalación fija una fecha memorable en los destinos de la patria, porque, respondiendo a los anhelos del país, hoy se inicia la transformación de su sistema judicial, bajo el signo de la integridad ética y de la honestidad profesional, con soluciones legales, prontas y eficaces [...] de acuerdo con las exigencias de la vida y de los derechos que tienen los ciudadanos para esperar pronta y eficaz justicia.

Rojas opinaba que la reforma constitucional de 1910 había errado al dejar al Congreso la facultad de elegir a los magistrados de la Corte Suprema pues la había convertido en lugar de "mezquinas ambiciones banderizas", y habia abierto las puertas "para que en los tribunales y juzgados primaran las intrigas y demás consideraciones extrañas al buen servicio". De ahí que insistiera en que el modo como él había integrado la nueva Corte gozaba de amplio respaldo ciudadano porque buscaba alejar el sectarismo faccioso de la Corte y de la rama judicial. Además, insistió en que en la reforma constitucional que discutiria la ANAC propondría que el jefe del Estado fuera quien designara libremente a la Corte Suprema de Justicia, cuyos magistrados serían vitalicios ${ }^{80}$.

La respuesta de la Corte al discurso de Rojas le correspondió a Eduardo Rodríguez Piñeres, un connotado jurista y el más veterano en la corporación, quien expresó que el Gobierno había dado claras muestras de que el poder judicial tendría en adelante el más alto lugar que jamás había tenido. Rodríguez no sólo elogió la iniciativa de reforma constitucional de Rojas, sino que propuso que el mismo general

78 El control constitucional del estado de sitio y las reformas constitucionales que ejerció esta Corte nombrada por Rojas decidió sobre varias demandas de inconstitucionalidad en contra de medidas dictadas al amparo del estado de sitio y en ellas en tribunal no desaprovechó la ocasión para fijar doctrinas legales que permitian al gobierno militar ejercer amplias facultades bajo el régimen del estado de sitio. Mario Alberto Cajas Sarria, "La Corte Suprema de Justicia bajo el gobierno del general Gustavo Rojas Pinilla”, op. cit. 18.

79 “Justicia sin sectarismo pide el Presidente Rojas Pinilla". El Tiempo. 2 de febrero de 1954, 1 y

80 Ibíd. P. 18. 
"designe por primera vez una vez expedida la reforma constitucional, una Corte Suprema de Justicia". Además, dijo: "Yo creo que hay que completar la obra de manera más firme, más sólida, dándole a esa nueva Corte el carácter de vitalicia, desde luego vigilada por el Ministerio de Justicia (...) Pero debemos también tratar de que el cuerpo judicial formado por ella y los tribunales y Juzgados sea como el Ejército, como la Iglesia, una institución enteramente independiente"81.

\subsection{Rojas quiere gobernar con menos límites: la Sala de Negocios Constitucionales de 1956}

La Asamblea Nacional Constituyente -ANAC-, que recordemos fue convocada por el gobierno de Laureano Gómez mediante acto legislativo aprobado por el Congreso de la República en 1952, era un órgano colegiado que debía cumplir las funciones de cuerpo constituyente pero tras el golpe del general Rojas se había convertido también en legislador ordinario. Como se dijo atrás en, 1953 la ANAC legitimó el golpe militar de 1953 y “convalidó” la permanencia del general Rojas en la presidencia hasta 1954. Gracias al dominio de Rojas sobre la ANAC, mediante el Acto Legislativo $\mathrm{N}^{\circ} 01$ del 30 de julio de 1954 ese mismo órgano amplió el número de sus miembros incluyendo representantes de las Fuerzas Armadas y de la Iglesia católica, y determinó que el 3 de agosto elegiría al Presidente de la República para el período 1954-1958, decisión que en efecto recayó en el general Gustavo Rojas Pinilla.

Esta última reforma activó la alarma en el Partido Liberal e hizo que esa fuerza política se fuera alejando del gobierno pues empezaban a preocuparse de que Rojas quisiera permanecer en su cargo por mucho tiempo. Además, porque si bien el acto legislativo determinó la integración paritaria de la ANAC también estableció que el gobierno elegiria 22 representantes liberales de una lista de 152 nombres propuestos por el Partido Liberal, pero al final Rojas solo seleccionó a 15 de la lista y a los 7 restantes los escogió a su arbitrio ${ }^{82}$.

Para mediados de 1956 el general Rojas había decidido conformar una plataforma politica propia. Rojas, impulsando la "Tercera Fuerza", que buscaba consolidar su proyecto político uniendo a los sectores populares con las Fuerzas Armadas en el poder. También había impuesto un severo régimen de censura de la prensa, incluido el cierre de los principales periódicos bogotanos de circulación nacional ${ }^{83}$ - El régimen se había endurecido y ya no tenía el respaldo de los partidos

81 Corte Suprema de Justicia, Sala Plena, Respuesta dada por el Dr. Eduardo Rodriguez Piñeres al discurso pronunciado por el Excmo. Señor Presidente de la República, Teniente General Gustavo Rojas Pinilla, al dar posesión a los honorables magistrados,. Gaceta Judicial LXXVII, N²138/2139,1 de febrero de 1954.

82 Adolfo León Atehortúa, "El golpe de Rojas y el poder de los militares”. Revista Folios Segunda época, 31: 33-48.: Universidad Pedagógica Nacional, Tunja, 2010. P. 41.

83 "Para entonces, el carácter transitorio del gobierno de Rojas se convirtió en indefinido; no se auto-vislumbraba como puente para facilitar el retorno de la democracia y los partidos, sino como 
politicos tradicionales: los líderes de los partidos Liberal y Conservador habían iniciado conversaciones en lo que se llamaria el Frente Civil, que apuntaba a un pronto regreso a la democracia, al gobierno civil. ${ }^{84}$ En tal contexto Rojas decidió dar un asalto más a la independencia de la Corte Suprema de Justicia, que parecía inspirarse en el proyecto de reforma constitucional del año 1953, cuando propuso crear el TGC. Ahora buscaba establecer una "Sala de Negocios Constitucionales" dentro de la propia Corte, que en adelante se encargaría de los juicios de constitucionalidad.

En esta ocasión las cosas no se quedaron en propuestas y mediante el Decreto legislativo $\mathrm{n}^{\circ} 1762$ del 26 de julio de 1956 el general Rojas creó la nueva Sala conformada por ocho magistrados provenientes de las demás Salas de la Corte Suprema de Justicia. La función de la Sala de Negocios Constitucionales sería: "decidir definitivamente sobre la constitucionalidad de los actos legislativos objetados por el gobierno como inconstitucionales o de las leyes o decretos que de conformidad con la Constitución puedan ser acusados ante ella por cualquier ciudadano, previa audiencia del Procurador General de la Nación"85.

La creación de la Sala de Negocios Constitucionales generó gran inconformidad en la comunidad jurídica. Por ejemplo, el Colegio de Abogados y de Juristas de Medellín y Antioquia le escribió una carta al general Rojas Pinilla expresando que la reforma era contraria a la Constitución. Rojas les contestó que su decisión se ajustaba a la Carta Política pues ésta sólo consagraba que la Corte Suprema de Justicia se dividiría en salas pero de ninguna manera ordenaba que el pleno del Tribunal debía conocer los juicios de constitucionalidad, asi que el Gobierno podía asignar esa función a la Sala de Negocios. Rojas también aprovechó para defender la medida, señaló que con ella se mejoraría la justicia pues ayudaria a descongestionar la Corte Suprema que estaba agobiada por la morosidad de los procesos de constitucionalidad. Además, volvió sobre el argumento técnico de la justicia constitucional integrada por especialistas en derecho público, como lo había hecho en su propuesta de reforma a la Corte en 195386:

gobierno perenne con el apoyo militar y en busca del respaldo popular. La Asamblea Nacional Constituyente no fue convocada para 1955 y la oposición se agudizó. La situación económica tampoco ayudó a Rojas: el precio del café cayó en el mercado internacional y la balanza de pagos se desequilibró, la inflación se disparó, el peso se devaluó frente al dólar y la reserva de divisas cayó. Rojas ganó la enemistad de los bancos con su política fiscalista y las facilidades de crédito que impuso en los bancos estatales, pero tuvo que ceder ante las ingentes presiones. El Banco Mundial y el FMI le obligaron a reducir las importaciones oficiales, a aumentar el encaje bancario y a prohibir los almacenes de depósito por parte de los bancos, entre otras medidas. La oposición de los empresarios arreció". Adolfo León Atehortúa, "El golpe de Rojas y el poder de los militares". Revista Folios Segunda época, 31, op. cit. P.42.

${ }^{84}$ Mario Alberto Cajas Sarria, "La Corte Suprema de Justicia bajo el gobierno del general Gustavo Rojas Pinilla”, op. cit. P. 136.

85 Presidencia de la República. Decreto 1762 del 26 de julio de 1956, Bogotá. Diario Oficial 29091, 1956.

86 Corte Suprema de Justicia, Proposición aprobada el 25 de septiembre de 1956. 422. 
Se creyó conveniente entonces crear la Sala de Negocios Constitucionales. Dedicada exclusivamente a conocer de tales asuntos, les daría evasión oportuna. Además, una Sala integrada por especialistas en la materia sería una garantía de acierto. Más que una Corte Plena, en la que por razones obvias no se puede aspirar a que cuando menos la mayoría de los magistrados sean especialistas en derecho constitucional. La Sala de Asuntos Constitucionales consagraría de este modo, en materia importante; la acertada y moderna tendencia de acabar con el conocimiento promiscuo en la administración de justicia de los países más adelantados y aspiración permanente de nuestros reformadores.

En las palabras de Rojas se aprecia con claridad el recurso a la "moderna tendencia" de los tribunales constitucionales especializados como argumento para reformar la justicia constitucional de la Corte Suprema de Justicia, justo cuando el Tribunal Constitucional Italiano ${ }^{87}$ empezaba a funcionar y el Tribunal Constitucional alemán había dado inicio a su trabajo.

Aunque la reforma propuesta por el gobierno militar bien podría ser vista como un paso hacia la tecnificación de la justicia constitucional colombiana, a la que nos hemos referido a lo largo de este trabajo, lo que realmente buscaba el Ejecutivo con el nuevo diseño institucional era lograr una mayor influencia en la Corte Suprema de Justicia. Gracias a la medida tomada por el gobierno militar, la Corte dejó de juzgar la constitucionalidad de los decretos de estado de sitio dictados por ele Ejecutivo así como los esporádicos actos legislativos de la ANAC y ahora esas funciones pasaban a ser competencia de una Sala de Negocios Constitucionales conformada por magistrados que el propio general Rojas seleccionó de entre quienes componian las Salas de la Corte Suprema de Justicia88. Estos fueron los magistrados designados para conformar la nueva sala: Daniel Anzola Escobar, Enrique Arámbula Durán (presidente), Abelardo Gómez Naranjo, Juan Manuel

87 Cappeletti, Mauro. "La justicia constitucional en Italia", en: XIII Boletín del Instituto de Derecho Comparado de México 41, 1960, traducción de Héctor Fix- Zamudio, México, D.F, UNAM.

88 El cambio en el diseño institucional de Rojas habría sido una reacción contra la Corte al conocer anticipadamente una decisión del tribunal que sería adversa al régimen. Así, luego de la caída de Rojas, en uno de los debates para preparar la transición al régimen civil, dijo uno de los integrantes de la Comisión Paritaria de Reajuste Institucional creada por la Junta Militar de Gobierno, Gonzalo Vargas Rubiano: "El acto más grave perpetrado por la dictadura contra las instituciones nacionales, después de la usurpación de la ANAC, fue el golpe de estado contra la ANAC producido con el decreto de julio de 1956. Decreto que fue el fruto oprobioso de una revelación hecha por unos magistrados que mancharon su investidura, porque violaron el secreto al que estaban obligados en las deliberaciones, llevaron a los oidos del César la noticia de que iba a salir una sentencia de inexequibillidad que rompia una vértebra a la dictadura". Según Vargas, luego de las renuncias de doce de los magistrados, Rojas: "procedió a llenar las sillas vacantes con personal dócil ante el estupor nacional. Y por eso Rojas anunció en aquella ocasión, en agosto de 1956, en un discurso en Barranca, que al fin el gobierno tenía una Corte amiga". "La Corte amiga" de Rojas debe borrarse del escenario nacional, dijo el doctor Gonzalo Vargas Rubiano en la paritaria”. El Tiempo, 8 de agosto de 1957. Pp. $1^{\mathrm{a}}$ y $9^{\mathrm{a}}$. 
Pachón Padilla, Camilo Rincón Lara, Sergio Antonio Ruano, Luis Sandoval Valcárcel y Domingo Sarasty ${ }^{89}$.

El decreto que creaba la Sala de Negocios Constitucionales produjo la renuncia inmediata de doce los magistrados que componían la Corte Suprema ${ }^{90}$ pero el general Rojas no tardó en aceptar las dimisiones y en nombrarles sendos reemplazos. Por su parte, la nueva Corte Suprema con su pequeño Tribunal Constitucional abordo manifestó públicamente su simpatía con el régimen, como se aprecia en la proposición de la sala plena de la corporación del 25 de septiembre de $1956^{91}$ :

La Corte Suprema de Justicia en Sala Plena, presenta su respetuoso saludo al Excelentísimo Señor Presidente de la República, Teniente General, Gustavo Rojas Pinilla, y al reconocer los altos sentimientos que lo animan a favor de una administración de justicia cada día más recta, pronta y eficaz, le manifiesta la voluntad de todos sus miembros de colaborar armónicamente en la realización de tan altos fines.

De este modo, la justicia constitucional colombiana funcionó con una Sala de Negocios Constitucionales dentro de la Corte Suprema de Justicia hasta que la Junta Militar de Gobierno, a la que el general Rojas le entregó el poder el 10 de mayo de 1957, decidió suprimirla el 18 de julio de 1957 para así devolverle a la Corte en pleno sus funciones atribuidas en la reforma de $1910^{92}$.

Como se puede apreciar, la justicia constitucional establecida por el general Gustavo Rojas Pinilla no era la del tribunal concentrado especializado que para la época se expandía por Europa. Por otra parte, es necesario rastrear las posibles relaciones de este diseño con el modelo cubano de la sala del Tribunal Supremo que se denominó Tribunal de Garantías Constitucionales y Sociales de la Carta Política de 1940. En suma, por obra del régimen militar el control constitucional de las leyes en Colombia permaneció a cargo de la Corte Suprema de Justicia, pero de una de sus salas: la creada y conformada al

${ }^{89}$ Mario Alberto Cajas Sarria, "La Corte Suprema de Justicia bajo el gobierno del general Gustavo Rojas Pinilla”. Op. cit. P. 138.

90 Renunciaron Luis Felipe Latorre, José J. Gómez, Manuel Barrera P., Aníbal Cardozo Gaitán, Roberto Goenaga, Agustín Gómez Prada, José Hernández Arbeláez, Ricardo Jordán J., Julio Pardo, José J. Rodriguez, Luis Zafra e Ignacio Gómez Posse. En su reemplazo nombró a Daniel Anzola Escobar, Enrique Arámbula Durán, José Enrique Arboleda Valencia, Jesús María Arias, Juan Benavides Patrón, Santiago Correa Copete, Miguel A. Constaín, Guillermo Garavito Durán, Guillermo Hernández P., José Jaramillo Giraldo, Pablo Emilio Manotas, Juan Manuel Pachón P., Sergio Antonio Ruano, Luis Sandoval Valcárcel, Elberto Téllez Camacho y Francisco de Paula Vargas. Presidencia de la República. Presidencia de la República. Decreto 1935 del 17 de agosto, 1956, Diario Oficial 29121, Bogotá, 1956.

91 Corte Suprema de Justicia, Proposición aprobada el 25 de septiembre de 1956 Gaceta Judicial LXXXII, n² 2171- 2173, P. 423.

92 "Abolida la Sala Constitucional en la Corte Suprema de Justicia", El Tiempo, 19 de julio de 1957. P. 1 y 17. 
arbitrio del general Gustavo Rojas Pinilla en $1956^{93}$.

\section{REFLEXIONES FINALES}

Este artículo examinó las reformas y los intentos de reforma a la justicia constitucional colombiana del general Gustavo Rojas Pinilla entre 1953 y 1957. Las dos iniciativas reformistas del régimen militar buscaban modificar el control constitucional de las leyes que la reforma constitucional de 1910 le había atribuido a la Corte Suprema de Justicia.

El trabajo reveló cómo las iniciativas reformistas del general Rojas al control constitucional de la Corte Suprema de Justicia en 1953 y 1956 se inscribieron en contextos de tensiones políticas ante los intentos del Ejecutivo de dominar la rama judicial, aun cuando el régimen militar argumentara que el móvil de tales reformas era la "tecnificación" de la justicia constitucional colombiana. De este modo, el gobierno del general Gustavo Rojas Pinilla, que suele caracterizarse como la dictadura que rompe con el régimen civil en 1953, aparece como protagonista del "fortalecimiento" de la defensa judicial de la Constitución.

De igual modo, es importante tener en cuenta que la trayectoria de los intentos por modificar la justicia constitucional colombiana no se agotaría con el gobierno de Rojas sino que continuarian con iniciativas, proyectos y reformas constitucionales en 1957,1968, 1977 y 1979, hasta llegar a la creación de la actual Corte Constitucional en la Constitución de 1991. En todas ellas se invocaría el modelo de justicia constitucional europeo de inspiración kelseniana, pero de las experiencias italiana y alemana, con lo cual la idea del Tribunal de Garantías Constitucionales de España de 1931 quedó en el olvido. En este sentido, queda abierto un camino para ahondar en las razones del ocultamiento de ese modelo, así como de las propuestas del general Rojas, que también hacen parte de la historia de la justicia constitucional colombiana.

Por último, este trabajo quiere insistir en la necesidad de explorar miradas distintas a la historia constitucional colombiana, que articulen los contextos políticos con las doctrinas legales de modo que puedan dar cuenta de las interdependencias complejas entre el derecho y la política en la construcción de la justicia constitucional.

93 Un análisis sobre la jurisprudencia de la Sala de Negocios Constitucionales en: Mario Alberto Cajas Sarria, "La Corte Suprema de Justicia bajo el gobierno del general Gustavo Rojas Pinilla", op. cit. 


\section{Bibliografía}

Héctor Álvarez García, "La naturaleza política del Tribunal de Garantías Constitucionales de la segunda república española" Revista de Derecho Político, UNED, No. 80, enero-abril 2011.

Asamblea Nacional Constituyente (ANAC). Acto legislativo 1 del 18 de junio de 1953. Diario Oficial No. 28329 del 24 de octubre de1953, Bogotá.

Asamblea Nacional Constituyente (ANAC). Acto legislativo 1 del 30 de julio de 1954, Diario Oficial 28607, Bogotá, 1954.

Asamblea Nacional Constituyente (ANAC). Acto legislativo 2 del 24 de agosto de 1954. Diario Oficial 28607, Bogotá, 1954.

Adolfo León Atehortúa. "El golpe de Rojas y el poder de los militares". Revista Folios Segunda época, 31: 33-48.: Universidad Pedagógica Nacional, Tunja, 2010.

César Augusto Ayala. "El discurso de la reconciliación. Análisis cuantitativo de las intervenciones de Gustavo Rojas Pinilla entre 1952 y 1959". Anuario Colombiano de Historia Social y de la Cultura 18/19, 1991.

Andrés Botero Bernal. "Haciendo memoria de la defensa judicial de la Constitución”, Pensamiento Jurídico, No. 20, Bogotá, 2007.

Mario Alberto Cajas Sarria. El control judicial a la reforma constitucional, 19102007, Universidad Icesi, Cali, 2008.

Mario Alberto Cajas Sarria. "La Corte Suprema de Justicia de Colombia, 18861910: de juez de la Regeneración a juez constitucional", Historia Constitucional, No. 14, Universidad de Oviedo, Oviedo, 2013.

Mario Alberto Cajas Sarria. "La Corte Suprema de Justicia bajo el gobierno del general Gustavo Rojas Pinilla" Revista de Estudios Sociales 50, Universidad de los Andes, Bogotá, 2014.

Mario Alberto Cajas Sarria. La Historia de la Corte Suprema de Justicia, 18861991, Tomo I: De la Regeneración al régimen militar, 1886-1958 y Tomo II: Del Frente Nacional a la Asamblea Constituyent, 1958-1991. Universidad de los Andes y Universidad Icesi, Colección Historia y Materiales del Derecho, Bogotá, 2015.

Mauro Cappeletti. "La justicia constitucional en Italia", en: XIII Boletín del Instituto de Derecho Comparado de México 41, traducción de Héctor Fix- Zamudio, UNAM, México, D.F., 1960.

José Luis Cascajo Castro. "Kelsen y la Constitución española de 1931", Revista de Estudios Políticos No. 1 (Nueva Época), Centro de Estudios Políticos y Constitucionales, Madrid, 1978.

Congreso de la República, Acto legislativo 01 de 1952, Diario Oficial 28075 del 12 de diciembre de 1952- 
LA JUSTICIA CONSTITUCIONAL DEL GENERAL GUSTAVO ROJAS PINILLA...

Javier Corcuera Atienza. "La Constitución española de 1931 en la historia constitucional comparada", en: Fundamentos: Cuadernos monográficos de teoría del estado, derecho público e historia constitucional, No. 2, 2000.

Corte Suprema de Justicia, Sala Plena. Respuesta dada por el Dr. Eduardo Rodríguez Piñeres al discurso pronunciado por el Excmo. Señor Presidente de la República, Teniente General Gustavo Rojas Pinilla, al dar posesión a los honorables magistrados, $1^{\circ}$ de febrero de 1954. Gaceta Judicial LXXVII, n² 2138/2139, 1954.

Corte Suprema de Justicia. Proposición aprobada el 25 de septiembre de 1956. Gaceta Judicial LXXXII, n² 2171- 2173, 1956.

Justin Crowe. Building the Judiciary: Law, Courts and the Politics of Institutional Development. Princeton.: Princeton University Press, New Jersey, 2012.

Pedro Cruz Villalón, "Dos modos de regulación del control de constitucionalidad: Checoslovaquia (1920-1938) y España (1931-1936)". Revista Española de Derecho Constitucional Año 2, Número 5, Mayo-agosto 1982. Pp. 115-148.

Pedro Cruz Villalón. La formación del sistema europeo de control de constitucionalidad (1918-1939), CEC, Madrid, 1987.

José Reinaldo De Lima Lopes. El oráculo de Delfos: Consejo de Estado y derecho en Brasil Imperial, Fontamara, México, D.F. 2012.

Alberto Donadío y Silvia Gálvis: El jefe supremo. Rojas Pinilla en la violencia y en el poder. Planeta, Bogotá, 1988

El Tiempo. "Quedó en libertad Incondicional el Señor Felipe Echavarría", Bogotá, 5 de noviembre de 1953.

El Tiempo. "Reforma Judicial propone al País el Ministro del Ramo", Escobar C. Bogotá, 6 de noviembre de 1953.

El Tiempo. "Paz, Justicia, Libertad, postulados invariables del actual Gobierno: trascendental discurso del Presidente en Cartagena”. Bogotá, 12 de noviembre de 1953

El Tiempo. "La Corte renunció ayer por la indiscriminación de cargos". Bogotá, 14 de noviembre de 1953.

El Tiempo. “Justicia sin sectarismo pide el Presidente Rojas Pinilla”. Bogotá, 2 de febrero de 1954.

El Tiempo, "Abolida la Sala Constitucional en la Corte Suprema de Justicia", Bogotá, 19 de julio de 1957.

El Tiempo, "La Corte amiga" de Rojas debe borrarse del escenario nacional, dijo el doctor Gonzalo Vargas Rubiano en la paritaria”. Bogotá, 8 de agosto de 1957.

Antonio Escobar Camargo. "La reforma judicial: Conferencia del señor Ministro de Justicia, doctor Antonio Escobar Camargo, dictada el 5 de noviembre de 1953", Bogotá, Imprenta Nacional, 1953. 
Eduardo Ferrer Mac Gregor. "Niceto Alcalá Zamora y el derecho procesal constitucional", Panorámica del Derecho Procesal Constitucional, Marcial PonsUNAM, México D.F., 2013.

Héctor Fix- Zamudio. Los Tribunales Constitucionales y los Derechos Humanos, UNAM, México, D.F, 1980.

Domingo García Belaunde. "El Tribunal de Garantías Constitucionales y Sociales de Cuba" (1940-1952), Apéndices, Boletín Mexicano de Derecho Comparado, Vol. XXXVII, número 109, UNAM- IIJ, México, D.F., 2004.

Jesús García Torres: "El sistema Europeo de control de constitucionalidad: la historia manifiesta la esencia", Revista Española de Derecho Constitucional,Año 8, Número 24, septiembre- diciembre de 1988.

Tom Ginsburg y Tamir Moustafa (Eds.). Rule by Law: The Politics of Courts in Authoritarian Regimes, Cambridge University Press, 2008.

Jorge González Jácome. Entre la ley y la Constitución: una introducción histórica de la función institucional de la Corte Suprema de Justicia, 1886- 1915. Pontificia Universidad Javeriana, Facultad de Ciencias Jurídicas. Bogotá, 2007.

Jorge González Jácome. Estados de excepción y democracia liberal en América del Sur: Argentina, Chile y Colombia, 1920-1990, Editorial Pontificia Universidad Javeriana, Bogotá, 2015.

Mirkine B. Guetzevitch. Modernas Tendencias del Derecho Constitucional, Traducción del francés por Sabino Álvarez, Editorial Reus, Madrid, 1934.

Gretchen Helmke. Courts under constraints: Judges, Generals and Presidents in Argentina, Cambridge University Press, 2012.

James D. Henderson. Las ideas de Laureano Gómez.: Tercer Mundo Editores, Bogotá, 1985.

James D. Henderson. "El Proyecto de reforma constitucional conservador de 1953 en Colombia", Pp. 261- 279. Anuario Colombiano de Historia Social y de la Cultura, No. 13-14, Bogotá, 1986.

James D. Henderson. Modernization in Colombia: the Laureano Gómez years, 1889-1965, University Press of Florida, 2001.

James D. Henderson, La modernización en Colombia: los años de Laureano Gómez, 1889-1965. Traducción de Magdalena Holguín. Universidad de Antioquia, Medellin 2006.

Lisa Hilbink. Judges beyond Politics in Democracy and Dictatorship: Lessons from Chile, Cambridge University Press, 2007.

Timothy M James. Mexico's Supreme Court: Between Liberal, Individual and Revolutionary Social Rights, 1867-1914.:University of New Mexico Press, Albuquerque, 2013. 
LA JUSTICIA CONSTITUCIONAL DEL GENERAL GUSTAVO ROJAS PINILLA...

Hans Kelsen. ¿Quién debe ser el defensor de la Constitución?, Tecnos, Madrid, 1995.

Sara Lagi. "Hans Kelsen and the Austrian Constitutional Court", 1918-1929, Revista Co-herencia, Vol 9, No. 16, enero-junio, 2012. 273-295.

Vernon Lee Fluharty. La danza de los millones. Régimen militar y revolución social en Colombia (1930-1956). El Áncora Editores, Bogotá, 1981.

Miguel Malagón Pinzón y Diego Nicolás Pardo Motta. "Laureano Gómez, la Misión Currie y el proyecto de reforma constitucional de 1952", Criterio Jurídico, V. 9. No. 2, Cali, 2009. P.10.

Sebastián Martin. El derecho politico en la segunda república: Francisco Ayala, Eduardo L. Llorens y Nicolás Pérez Serrano, Estudio preliminar, edición y notas de, Universidad Carlos III de Madrid- Dykinson, Madrid. 2011.

Andry Matilla Correa: "El control jurisdiccional en la constitucionalidad cubana de 1901".En: Escritos sobre derecho procesal constitucional, homenaje cubano al profesor Héctor Fix Zamundio en sus 50 años como investigador del Derecho, IIjUNAM, Universidad de la Habana, La Habana, 2012. P. 169-252.

Ministerio de Justicia. Decreto 3110 del 27 de noviembre de 1953. Diario Oficial 28359, Bogotá, 1953.

Ministerio de Gobierno, Estudios Constitucionales, Tomos I y II, Imprenta Nacional, Bogotá, 1953.

Eduardo Oteiza, La Corte Suprema: entre la justicia sin politica y la politica sin justicia, Libreria Editora Platense, La Plata, 1994.

Marco Palacios. Entre la legitimidad y la violencia. Colombia, 1857-1994. Norma, Bogotá, 2004.

José F. Palomino Manchego "Los orígenes de los Tribunales Constitucionales en América Latina", en: El derecho público a comienzos del siglo XXI: estudios en homenaje al profesor Allan R. Brewer Carias, Alfredo Arismendi y A., Jesús Caballero Ortiz (Coord.) Vol. 1, Civitas, Madrid, 2003.

Daniel Pécaut, Orden y Violencia, Colombia, 1930-1954, CEREC, Bogotá, 1987.

William Freddy Pérez. "El sistema penal y la emergencia en Colombia". Scripta Nova. Revista Electrónica de Geografía y Ciencias Sociales 45. Barcelona, 1999. Disponible en: <http://www.ub.edu/geocrit/sn-45-24.htm>.

Presidencia de la República, Decreto 3110 del 27 de noviembre de 1953, Diario Oficial Año XC, No. 28359, Bogotá, 30 de noviembre de 1954.

Presidencia de la República. Decreto 1762 del 26 de julio de 1956, Bogotá. Diario Oficial 29091, 1956. 
Presidencia de la República. Decreto 1935 del 17 de agosto, 1956, Diario Oficial 29121, Bogotá, 1956.

Proyecto de Reformas presentado al Ministerio de Gobierno por la Comisión de Estudios Constitucionales, Bogotá, febrero 11 de 1953. Universidad Pontificia Bolivariana, Revista de Derecho, pp- 85-123. Disponible en: https://revistas.upb.edu.co/index.php/derecho/article/view/5011. Recuperado el 4 de enero de 2016.

Carlos Restrepo Piedrahita. Tres ideas constitucionales: Supremacía de la Constitución, Corte Constitucional, El Ombudsman. Universidad Externado de Colombia, Bogotá, 1978.

Carlos Restrepo Piedrahita (Comp.), Constituciones Nacionales de Colombia, $3^{\mathrm{a}}$ edición,. Universidad Externado de Colombia, Bogotá 2003.

Francisco Rubio Llorente. "Del Tribunal de Garantías al Tribunal Constitucional" Revista de Derecho Político No. 16, Invierno, 1982-1985, Madrid, 1985.

Eduardo Sáenz Rovner, Colombia Años 50: Industriales, política y diplomacia, Universidad Nacional de Colombia, 2002.

Juan Pablo Sarmiento. Surgimiento de la dualidad de jurisdicciones en Colombia: entre la dictadura y la Unión Republicana. Universidad del Norte. Barranquilla, 2012.

Eustorgio Sarria: Tratado de Derecho Administrativo, segunda edición, Crítica Jurídica, Bogotá, 1952.

Boaventura Souza Santos y Mauricio García Villegas. El Caleidoscopio de las Justicias en Colombia. Bogotá, Colciencias, ICANH, Uniandes, Universidad Nacional de Colombia, Siglo del Hombre Editores. Bogotá, 2001.

Héctor José Tanzi. "Historia ideológica de la Corte Suprema de Justicia de la Nación (1903-1930)", Revista Iushistoria No. 1, Buenos Aires, 2008.

Álvaro Tirado Mejía. "El gobierno de Laureano Gómez: de la dictadura civil a la dictadura militar". En Nueva Historia de Colombia: Historia Politica, 1946-1986, Dir. Álvaro Tirado Mejía. Planeta, Bogotá, 1989.

Álvaro Tirado Mejía. "Rojas Pinilla: del golpe de opinión al exilio". En Nueva Historia de Colombia: Historia Politica, 1946-1986, Dir. Álvaro Tirado Mejía. Bogotá: Planeta, Bogotá, 1989.

Carlos Horacio Urán. Rojas y la manipulación del poder: Rojas Pinilla en la violencia y el poder. Carlos Valencia Editores, Bogotá,1983. 
Alberto Valencia Gutiérrez, "El juicio a Rojas Pinilla y la construcción de la memoria colectiva en los años cincuenta en Colombia", Universitas Humanística No.72, julio-diciembre de 2011. Bogotá, PP. 15-36.

Enviado el / Submission Date: 7-01-2016

Aceptado el / Acceptance Date: 29-03-2016 